VARELA, Luis. "Delitos contables mercantiles en el Derecho penal económico chileno: Sistematización de su marco regulatorio, elementos comunes de sus tipos penales y desafíos pendientes".

Polít. crim. Vol. 11, No 21 (Julio 2016), Art. 10, pp. 264-306.

[http://www.politicacriminal.cl/Vol_11/n_21/Vol11N21A10.pdf]

\title{
Delitos contables mercantiles en el Derecho penal económico chileno: Sistematización de su marco regulatorio, elementos comunes de sus tipos penales y desafíos pendientes
}

\section{Commercial accounting fraud in Chilean penal economic law: Systematization of its regulatory framework, common elements of their penal types and pending challenges}

\author{
Luis Varela Ventura* \\ Universidad Antofagasta - Universität Heidelberg \\ luis.varela@uantof.cl
}

\section{Resumen}

El artículo expone una introducción al Derecho penal de los estados financieros desde una perspectiva comparada. Luego propone una sistematización del marco regulatorio de la contabilidad mercantil en Chile, especialmente en cuanto a sus reglas de confección, exhibición y auditoría. Finalmente, se identifican los tipos penales contables mercantiles presentes en la ley penal chilena y se analizan sus elementos comunes. En la conclusión se confronta el estado actual de la materia, su relación con la tendencia internacional y nuevos desafíos.

Palabras clave: Derecho penal económico, estados financieros, contabilidad, delitos contables.

\section{Zusammenfassung}

Der Aufsatz tut eine Einführung in das Rechnungslegungsrecht aus einer vergleichenden rechtlichen Perspektive dar. Dann schlägt eine Systematisierung des Rechtsrahmens des Handelsbilanzrechts in Chile, besonderes seiner Buchführung-, Darstellung-, und Abschlussprüfungsregeln vor. Schließlich identifiziert man die jeweiligen strafrechtlichen Tatbestände und ihre gemeinsamen Merkmale werden erklärt. Im Fazit stellt man den Zustand des Bereichs mit der internationalen Tendenz und die neuen Herausforderungen gegenüber.

Stichworte: Wirtschaftsstrafrecht, Rechnungslegung, Bilanz, Bilanzdelikte.

\footnotetext{
* Académico investigador de la Facultad de Ciencias jurídicas de la Universidad de Antofagasta, becario Conicyt para estudios de doctorado en el extranjero, estudiante de doctorado e investigador invitado en la Ruprecht-Karls-Universität Heidelberg. El presente artículo forma parte del trabajo doctoral del autor titulado "Systematisierung und Harmonisierung des Bilanzstrafrechts im iberoamerikanischen OECD-Rahmen", dirigido por el Prof. Dr. Gerhard Dannecker, Director del Institut für deutsches, europäisches und internationales Strafrecht und Strafprozessrecht de la Juristischen Fakultät Universität Heidelberg. Este artículo es el primero de una serie de cuatro seminarios en que se aborda el tema. Contacto en http://www.jura.uni-heidelberg.de/dannecker/lehrstuhl/luis_varela_ventura.html
} 


\section{VARELA, Luis. "Delitos contables mercantiles en el Derecho penal económico chileno: Sistematización de su marco regulatorio, elementos comunes de sus tipos penales y desafíos pendientes".}

\section{Introducción}

Estados financieros correctos, oportunos y trasparentes, que reflejen plenamente la situación patrimonial de una empresa, es presupuesto esencial para el buen funcionamiento de la economía de libre mercado y para el adecuado tráfico jurídico en el mundo globalizado ${ }^{1}$. Al servicio de esto, la ciencia contable ha avanzado en el perfeccionamiento de estándares de confección, presentación y auditoría, para cumplir de mejor forma con este fin $^{2}$. El Derecho ha acompañado dicho desarrollo con reglas de control de la información patrimonial, prestando cuando el caso lo requiera, tutela penal a los bienes jurídicos involucrados en dicho contexto ${ }^{3}$.

\footnotetext{
${ }^{1}$ Esto reconocido por economistas, contadores-auditores, y juristas. Ver GRATOPP, Jutta, Bilanzdelikte nach § 331 Nr. 1, Nr. la HGB, Münster: Lit-Verl., 2009, pp. 21-23; SCHMEDDING, Detlef, Unrichtige Konzernrechnungslegung : zur Strafbarkeit unrichtiger oder verschleiernder Darstellungen im neuen Konzernbilanzrecht nach $\$ 331$ Nr. 2 HGB, Heidelberg: Müller, 1991, p. 14. Quien destaca el daño que puede causar a la economía una mala regulación de estos aspectos.
}

2 EMMRICH, Markus, Ansätze und Perspektiven einer Reform der externen Rechnungslegung in Deutschladn, Aachen: Schaker, 1999, pp. 8-42. La historia de la contabilidad y de la confección de estados financieros, no obstante tiene antecedentes en Roma, ver SCHÜPPEN, Matthias, Systematik und Auslegung des Bilanzstrafrechts, Köln: Schmidt, 1993, p. 60, está íntimamente ligada a la introducción de los números arábigos por parte de Fibonacci en las antiguas repúblicas mercantiles del norte italiano, en el denominado primer Renacimiento (S. XII), ver GOETZMANN, William, "Fibonacci and the Financial Revolution", NBER Working Paper, $\mathrm{n}^{\circ} 10352$ (2004), pp. 6-35, y a sus aplicaciones prácticas por parte del fraile franciscano Luca Pacioli, inventor del denominado "Libro de partida doble", como forma de control de las finanzas de su convento, ver SANGSTER, Alan; Scataglinibelguitar, Giovanna, "Luca Pacioli: The Father of Accounting", Accounting Education: an international journal Education, Vol. 19 (2010), pp. 424-438, aunque no ha faltado el autor que afirma que ha sido otro el precursor de este sistema, ver HERNÁNDEZ, Esteban, "Benedetto Cotrugli, precursor de Paciolli en la exposición de la partida doble", Cuadernos de Estudios Empresariales (Madrid), n 2 (1992), pp. 87-99. Este sistema fue utilizado luego por las grandes Compagnia y desde ahí se introdujo entre los mercatores y banqueros de las repúblicas del Renacimiento italiano del S. XV, ver CIPOLLA, Carlo, Geld-Abenteuer: Extravagante Geschichten aus dem europäischen Wirtschaftsleben, Berlin: Wagenbach, 1995, p. 11. Luego, la VOC (Vereenigde Oostindische Compagnie) de las Provincia Unidas (hoy Países Bajos), la primera gran Sociedad anónima del mundo moderno, adoptó en el año 1623, por vez primera, la rendición de cuentas del directorio para con sus accionistas, como también las auditorias de sus estados financieros, y ambos, como procesos periódicos, ver FRENTROP, Paul, A History of Corporate Governance 1602-2002, Amsterdam: Deminor, 2003, p. 85. Este sistema contable fue luego recogido legalmente por el Derecho común, como obligación de todo comerciante, primero en Francia, en las "Ordennance de Commerce" de 1637, y desde ahí pasó en el periodo de la Codificación a los distintos códigos continentales y al ámbito anglosajón, ver RÜCKERT, Sabrina, Die Einführung der obligatorischen Buchführung: eine rechtshistorische Untersuchung über die Anfänge und die Entwicklung des Bilanzrechts in Frankreich und Deutschland, Berlin; Münster: Lit, 2009, p. 96. El sistema de contabilidad se mantuvo en general inalterable hasta la irrupción a fines del siglo XIX y principios del XX de la denominada contabilidad de costos. Con el surgimiento en el espacio anglosajón de las grandes firmas de auditoría contable comenzó la etapa moderna de la confección de estados financieras, estableciéndose reglas técnicas que han alentado la convergencia de sistemas contables en el ámbito internacional, ver MEKAT, Martin, Der Grundsatz der Wesentlichkeit in Rechnungslegung und Abschlussprüfung, Baden-Baden: Nomos, 2009, pp. 39-43.

${ }^{3}$ TIEDEMANN, Klaus, Wirtschaftsstrafrecht : Einführung und Allgemeiner Teil mit wichtigen Rechtstexten, 4. Aufl., München: Vahlen, 2014, p. 55. El citado autor señala, que dentro del sistema del Derecho penal económico existen una serie de "bloques legislativos" presentes en leyes penales especiales que regulan áreas concretas del orden público económico. El Derecho penal de los estados financieros sería uno de estos bloques. 
Polít. crim. Vol. 11, No 21 (Julio 2016), Art. 10, pp. 264-306.

[http://www.politicacriminal.cl/Vol_11/n_21/Vol11N21A10.pdf]

Las proyecciones de este bloque son tan variadas, que es posible encontrar sus tipos penales y sancionatorios tanto en el Derecho mercantil (societario, del mercado de capitales, bancario), en la legislación tributaria, en los tipos penales de la insolvencia, como, asimismo, en variadas áreas en las cuales la transparencia y la confianza son un elemento esencial de su funcionamiento ${ }^{4}$.

En Chile la dogmática penal no ha abordado el tema de forma sistemática, tal vez porque se considera éste un espacio limítrofe entre Derecho penal, Derecho comercial y la contabilidad jurídicamente regulada, por lo anterior, el presente trabajo busca hacerse cargo de dicho vacío, para lo cual se propondrá una tentativa de sistematización del marco que regula los estados financieros, para luego identificar las distintas figuras penales que califican como delito contable mercantil y plantear un análisis dogmático preliminar de los elementos comunes de éstos, para finalmente destacar el estado de avance de la legislación interna en relación a la tendencia internacional señalando los principales desafíos dogmáticos y político criminales de esta área.

\section{Generalidades.}

\subsection{Breves consideraciones sobre la tendencia internacional y relevancia en Derecho comparado.}

Numerosos instrumentos emanados de importantes organizaciones internacionales se han hecho cargo de la regulación de los estados financieros empresariales. Sobresalen en este sentido, los esfuerzos de la OCDE y de la UE para elevar los estándares contables vigentes de sus Estados, como asimismo en cuanto a la introducción de tipos que sancionen las conductas contrarias a éstos.

En el contexto de la UE, estos esfuerzos se han efectuado a propósito del proceso de armonización del Derecho societario, en el cual se aprobó numerosa normativa comunitaria sobre confección y auditoría de estados financieros, regulación societaria, gobiernos corporativos, mercado de capitales ${ }^{5}$, entre otros aspectos afines. Se fomentó además

\footnotetext{
4 DANNECKER, Gerhard, "Die Bekämpfung der Korruption in Deutschland durch das Straf- und Steuerrecht", en: DANNECKER, Gerhard (Ed.), Handbuch Korruption, Wien: Linde, 2012, pp.199-207, para quien el balance tributario anual serían un medio idóneo para detectar dineros "no limpios", y luchar contra la corrupción en el ámbito privado, ver FOFFANI, Luigi, "Delitos societarios", traducción de BRANDARIZ, José y PUENTE, Luz, en: FARALDO, Patricia y VALEIJE, Inmaculada (Eds.), Actas I Congreso hispanoitaliano de derecho penal económico, La Coruña: Publicaciones de la Universidad de la Coruña, 1998, p. 60, coloca como ejemplo el caso "Tangentopoli" en Italia, que evidenció la ilegalidad político-administrativa desde la corrupción a la financiación ilícita de los partidos, las cuales estarían estrechamente vinculados a estas formas de ilegalidad económica.

${ }^{5}$ Fundamentales para la convergencia de reglas sobre estas materias en el espacio de la UE:

Sobre contabilidad en general: La Cuarta Directiva 78/660/CEE (25.07.1978) sobre armonización de la contabilidad de los Estados miembros, la Directiva 86/635/CEE (08.12.1986) relativa a cuentas anuales y consolidadas de los bancos, la Directiva 89/117/CEE (13.02.1989) relativa a obligaciones en materia de publicidad de los documentos contables de las sucursales de sociedades establecidas en un Estado miembro, de entidades de crédito y financieras con sede social fuera de dicho Estado. Sobre armonización del Derecho societario en lo referente a sus estados financieros: la primera Directiva 68/151 CEE (09.03.1968) sobre Sociedades, que armoniza varios ámbitos, incluido las reglas sobre estados financieros, directiva que fue
} 
VARELA, Luis. "Delitos contables mercantiles en el Derecho penal económico chileno: Sistematización de su marco regulatorio, elementos comunes de sus tipos penales y desafíos pendientes".

decididamente la tipificación de delitos contables en los Derechos penales internos, destacando en este sentido, el Convenio penal sobre corrupción del Consejo de Europa de 17.01.1999 (en adelante CPC-CE) ${ }^{6}$, cuyo art. 14, en palabras de Dannecker, es un reflejo de; "la necesidad de protección penal de los estados financieros", a nivel europeo, en razón de su significación para "el tráfico económico comunitario"7. El referido artículo, titulado "delitos contables", vino a establecer la obligación de todo Estado miembro de la UE de adoptar medidas legislativas que regulen como hecho punible, con sanciones penales o de otro tipo, las conductas dolosas destinadas a "cometer", "ocultar" o "disimular" por medio de la contabilidad los delitos de corrupción pública y privada contempladas en el propio convenio (arts. 2 al 12 CPC-CE), el delito contable tributario de extender o utilizar facturas falsas, el delito contable mercantil de entregar información falsa o incompleta sobre los estados financieros de una empresa (art. 14 letra a CPC-CE), y la omisión de contabilidad (art. 14 letra b CPC-CE).

En el mismo espíritu y conforme a la tendencia mundial ${ }^{8}$, se introdujo al Derecho comunitario una serie de directrices y recomendaciones para perfeccionar el sistema contable vigente en la zona de la $\mathrm{UE}^{9}$. Ejemplo de estas normativas comunitarias son la Directrices UE 2004/109/CE (15.02.2004) -y la 2006/43/CE (17.05.2006) ${ }^{10}$, siendo esta

complementada por otras posteriores, dentro de las cuales la cuarta, séptima, y octava tienen especial importancia. La Directiva 83/350/ CEE (13.06.1983) relativa a vigilancia de instituciones de crédito basada en su situación consolidada. Sobre introducción de las nuevas IFRS en el ámbito de la EU, el Reglamento 1602/2002 (19.07.2002) y sus respectivas modificaciones y protocolos. Sobre regulación del mercado de valores e información que debe ser entregada en este contexto: la Directiva 80/390/CEE (27.03.1980) sobre elaboración control y difusión del prospecto que se publica para la admisión de valores mobiliarios a la cotización oficial en una Bolsa de valores, Directiva 82/121/CEE (15.02.1982) sobre información periódica que deben entregar sociedades que sean oficialmente admitidas a transar en una Bolsa de valores, la Directiva 82/148/CEE (03.03.1982) que modifica la Directiva 79/279/CEE sobre coordinación de las condiciones de admisión de valores mobiliarios a cotización oficial en una Bolsa de valores, y la Directiva 80/390/CEE sobre coordinación de las condiciones de establecimiento control y difusión del folleto que debe publicarse para la admisión de valores mobiliarios a cotización oficial en una Bolsa de valores. La Directiva 88/627/CEE (12.012.1988) sobre las informaciones que han de publicarse en el momento de la adquisición y de la cesión de una participación importante en una sociedad cotizada en Bolsa. Entre muchas otras que se refieren indirectamente al tema.

${ }^{6}$ Conocido en el espacio germano parlante como Strafrechtsübereinkommen des Europarats über Korruption.

7 DANNECKER, Gerhard, "Bilanzdelikte im internationalen Kontext", en: KEPPERT, Thomas (Ed.), Bilanzdelikte, Wien: Linde, 2009, p. 103.

${ }^{8}$ WAßMER, Paul "Vorbemerkungen zu $\S$ 331-335b (HGB)", en: HENNRICHS, Joachim; KLEINDIEK, Detlef, et al. (Eds.), Münchener Kommentar zum Bilanzrecht II $\$ \$ 238$ - 342 e HGB, München: Beck, 2013, n.m. 4. Para quien el desarrollo del Bilanzstrafrecht estaría desarrollándose no dentro de un contexto de europeización sino de globalización.

${ }^{9}$ MOCK, Sebastian, Finanzverfassung der Kapitalgesellschaften und internationale Rechnungslegung, Köln; München: Heymann, 2008, p. 74. Introducción a través del Derecho Europeo, que se vería reforzada por el efecto armonizador conforme al principio de primacía del Derecho comunitario y la interpretación conforme a éste, sobre el particular ver DANNECKER, Gerhard, Evolución del derecho penal y sancionador comunitario europeo, Madrid: Marcial Pons, 2001, pp. 63-67.

${ }^{10}$ Conocidas en el contexto alemán como Transparenzrichtlinie y Abschlussprüferrichtlinie. La primera, orientada a la claridad y transparencia de la información financiera individual de las empresas como asimismo de los estados financieros consolidados de los consorcios empresariales, y que ha promovido la entrega de informes semestrales junto a los acostumbrados anuales, además del establecimiento de un régimen de responsabilidad de los directivos empresariales por la información financiera salida desde la empresa. Por su 
Polít. crim. Vol. 11, № 21 (Julio 2016), Art. 10, pp. 264-306.

[http://www.politicacriminal.cl/Vol_11/n_21/Vol11N21A10.pdf]

última resaltada por generar una profunda convergencia entre la regulación norteamericana y la europea ${ }^{11}$.

A su vez, la OECD, agrupación a la cual pertenecen los países que aportan el $80 \%$ del PNB mundial -entre ellos Chile- también ha concedido gran importancia al tema, y le ha dedicado en consecuencia una serie de documentos ${ }^{12}$. Destacan en este sentido dos instrumentos: el primero "Principios de Gobierno Corporativo de la OECD" (2004), que en su punto $\mathrm{V}$ "Divulgación y datos de trasparencia" aconsejó la revelación oportuna y precisa de la información relativa la situación financiera de una empresa. ${ }^{13}$ En opinión del organismo:

“(...) un régimen divulgativo fuerte, que promueva una transparencia real, es una característica fundamental en el ámbito de la monitorización de sociedades basada en el mercado, y esencial para la capacidad de los accionistas para ejercitar sus derechos de propiedad de forma documentada. La experiencia en países con mercados de capitales importantes y activos nos demuestra que la divulgación de información puede ser también un poderoso instrumento para influir en el comportamiento de las empresas y proteger a los inversores. Un régimen divulgativo fuerte puede ayudar a atraer capital y a que los mercados de capital mantengan su confianza" [las cursivas son mías]. ${ }^{14}$

Dicho instrumento, ratifica lo dicho ya antes en "Principios de la OCDE para el gobierno de las sociedades" (1999), el cual, en su punto IV "Comunicación y transparencia informativa”, propuso que la información patrimonial de las empresas sea presentado de manera precisa y de modo regular, acerca de todas las cuestiones materiales referentes a la sociedad, incluidos los resultados, la situación financiera, la propiedad y el gobierno corporativo $^{15}$.

Otros instrumentos de la OCDE han desarrollado la cuestión, en otros contextos, como los estados financieros de empresas públicas, o respecto del control a través de sistema de auditorías $^{16}$. Este cuerpo de buenas prácticas y recomendaciones generados desde la OCDE,

parte, la segunda directiva citada, propugnó la elevación del nivel y la armonización comunitaria de las reglas sobre auditorías de estados financieros, fomentando también la introducción de tipos penales para conductas inadecuadas en este contexto.

${ }^{11}$ FLEISCHER, Ulrich, Die Strafbarkeit der Abgabe eines unrichtigen Bilanzeids gemäß $\S 331$ Nr. $3 a$ HGB, Berlin: Duncker \& Humblot, 2014, pp. 23-33. En el ámbito alemán se introdujo por ejemplo un nuevo delito contable de origen norteamericano denominado Bilanzeid, el cual tiene su origen en la Sarbanes-Oxley Act (en adelante SOA) de EEUU y que tiene como figura rectora - con particularidades-al perjurio.

${ }^{12}$ Sobre el porcentaje citado, ver OCDE Rapport annual (2007), disponible en www.oecd-ilibrary.org. [Consultado 15.12.2015]. Otros importantes instrumentos de la OECD sobre el tema son; "Corporate Governance Accountability and Transparency; a guide for state ownership " (2010), passim.

${ }^{13}$ OCDE: Principios Gobierno Corporativo (2004), pp. 22-23. Junto a la divulgación se propone sistema de auditoría independiente como garantía externa y objetiva de que los estados financieros reflejan fielmente la situación financiera de la empresa.

${ }^{14}$ OCDE: Principios (2004), cit. nota ${ }^{\circ} 13$, p. 49.

${ }^{15}$ OCDE: Principios gobiernos sociedades (1999), p. 46.

${ }^{16}$ Otros instrumentos OCDE relevantes para nuestro tema son: "Accountability and Transparency: A Guide for State Ownership" (2010), de la cual hay traducción como "Guía para rendición de cuentas y 
VARELA, Luis. "Delitos contables mercantiles en el Derecho penal económico chileno: Sistematización de su marco regulatorio, elementos comunes de sus tipos penales y desafíos pendientes".

unido a las evaluaciones de implementación a los que son sometidos periódicamente sus Estados, han sido un motor de cambios, modernización y armonización de gran importancia a nivel global, y esto no sólo para sus miembros, sino también para los distintos países que aspiran a serlo ${ }^{17}$.

En cuanto a la tendencia internacional, en Derecho comparado, es por todos citados la importancia gravitante que tuvo para los delitos contables el llamado "Caso Enron", y esto, no sólo en EEUU, sino también en el resto del mundo. ${ }^{18}$ Es posible afirmar, que existe un antes y un después marcado por dicho caso y por la legislación que motivó, la llamada Sarbanes-Oxley Act (30.07.2002) ${ }^{19}$, que introdujo una serie de reglas tendientes a fortalecer la implementación de sistemas de control de los estados financieros de las empresas norteamericanas (Sec. 302 SOA) y que creó una serie de delitos castigados con altísimas penas para sus responsables -hasta 20 años de privativa de la libertad y multas hasta U\$ 5.000.000 (Sec. 906 SOA) -. Cuando en otras latitudes, casos como Enron se descubrieron, por ejemplo; "Parmalat" en Italia, "Banesto" en España, "Consorcio Siemens" en Alemania, se tuvo a la vista la SOA como modelo a seguir para hacer las correspondientes reformas $^{20}$.

Alemania no ha quedado fuera de la tendencia, y en el contexto de la introducción de nuevos estándares contables ${ }^{21}$, coincidiendo asimismo con una ola de casos con connotaciones de Bilanzdelikt ${ }^{22}$, se introdujo modificaciones en distintos cuerpos legales que significaron la implementación plena de los instrumentos europeos arriba descritos, los cuales se plasmaron principalmente en la creación de delitos contables mercantiles de aplicación general a las sociedades de capital, y que fueron añadidos al §331 y ss. del libro

transparencia para Empresas de Propiedad del Estado, Líneas Directrices de la OCDE para Empresas Multinacionales" (2011), entre otros.

${ }^{17}$ En el caso de Iberoamérica, son tres los países pertenecientes a esta organización, España, Chile y México. En proceso de adhesión con cooperación reforzada, Brasil, en proceso de adhesión: Colombia, Costa Rica. Ver http://www.oecd.org/centrodemexico/paisesmiembros.htm [consultada por última vez el 15.11.2015]

${ }^{18}$ KREKLAU, Jan, Das US-amerikanische Bilanzstrafrecht - Vorbild für das deutsche Bilanzstrafrecht?, Bayreuth: Verl. P.C.O., 2008, pp. 22-25.

${ }^{19}$ Sobre Enron se han escrito muchas páginas. Solo citaremos el interesante trabajo de SCHÜNEMANN, Bernd, "The Sarbanes-Oxley Act of 2002: A German Perspective", Buffalo Criminal Law Review, 8 (2004), p 36 y ss., en que el autor expone desde la perspectiva alemana, y de su especial modelo aplicable a la criminalidad empresarial, explicada en SCHÜNEMANN, Bernd, Unternehmenskriminalität und Strafrecht : eine Untersuchung der Verantwortlichkeit der Unternehmen und ihrer Führungskräfte nach geltendem und geplantem Straf- und Ordnungswidrigkeitenrecht, Köln: Heymann, 1979, passim. Una versión resumida de esta obra en español en ADPCP 1988-II, pp. 529-558. Sobre el "legado" del caso Enron en EUU expresado en juicios contra CEO de grandes empresas por delitos contables y otros fraudes corporativos, cfr. BRICKEY, Kathleen, "A la estela de Enron: Ejecutivos de corporación en juicio", Anuario de Derecho penal económico y de la empresa, $\mathrm{n}^{\circ} 2$ (2012), pp. 145 y ss.

${ }^{20}$ SORGENFREI, Ulrich, "Zweifelsfragen zum , "Bilanzeid" (§ 331 Nr. 3a HGB)", Wistra, (2008), pp. 329330. DANNECKER, "Bilanzdelikte", cit. nota n 7, p. 106.

${ }^{21}$ Por medio de la Ley de modernización del Derecho contable (Bilanzrechtsmodernisierungsgesetz en adelante BilMog) de 29.05.2009.

${ }^{22}$ DANNECKER, Gerhard, "§§ 331 - 342e", VII-2, en: STAUB, Hermann (Ed.), Staub-HGB, VII-2, 5. Aufl., Berlin: De Gruyter, 2012, pp. 38-42, se ofrece una larga lista de casos ocurridos en Alemania. Entre los más famosos, junto al nombrado Siemens, los casos "Balsam AG" y "Telekom AG". 
Polít. crim. Vol. 11, No 21 (Julio 2016), Art. 10, pp. 264-306.

[http://www.politicacriminal.cl/Vol_11/n_21/Vol11N21A10.pdf]

III del Handelsgesetzbuch (Código de Comercio alemán en adelante HGB) en 1985, la creación de nuevas figuras de delincuencia contable en 2009 y una reciente reforma de 2015 que amplió la regulación a pequeñas y medianas empresas ${ }^{23}$.

España, siguiendo el derrotero europeo, ajustó su legislación a las tendencias comunitarias en los años noventa. A pesar de que su legislación penal contó con un interesante antecedente en el art. 734 del efímero Código Penal de 1928 que contempló un delito contable avanzado para su tiempo, los delitos contables mercantiles no fueron reintroducidos sino hasta la entrada en vigencia del Código penal (en adelante CPE) de 1995, el cual bajo la rúbrica "Delitos societarios" (art. 290 y ss.) estableció un genuino tipo penal de esta naturaleza ${ }^{24}$.

Chile tampoco ha quedado ajeno a estos $\operatorname{cambios}^{25}$, desde hace más de una década ha venido trabajando un largo proceso de modernización de las reglas de su derecho societario, gobierno corporativo y mercado de capitales ${ }^{26}$. En este proceso, y en cada una de las reformas introducidas, se ha mejorado la regulación del Derecho de los estados financieros a nivel corporativo. Con el ingreso de Chile a la OCDE en 2010, la agenda de introducción de buenas prácticas societarias en el país avanzó con mayor rapidez y profundidad ${ }^{27}$, no obstante lo cual, la ocurrencia de bullados casos que contienen elementos propios de delitos contables, como: Inverlink, La Polar, Penta, Cascadas y SQM, coloca en primera línea la necesidad de discusión político criminal y elaboración de una respuesta dogmática a la delincuencia que tratamos ${ }^{28}$.

\footnotetext{
${ }^{23}$ Las leyes en concreto fueron la Bilanzrichtliniengesetz (19.12.1985), la Bilanzrechtsmodernisierungsgesetz (25.05.2009) y la implementación de la Directriz Europea 2013/34/EU para presentación de estados financieros de pequeñas y medianas empresas por medio de la Bilanzrichtlinie-Umsetzungsgesetz (27.07.2015). Ver RANSIEK, Andreas, "8. Teil Gesellschaftsrechtliche Bilanz-, Prüfer und Falschangaben", en: ACHENBACH, Hans; RANSIEK, Andreas, et al. (Eds.), Handbuch Wirtschaftsstrafrecht, 4. Aufl., Heidelberg: Müller, 2015, pp. 965-969.

${ }^{24}$ En detalle sobre la historia de los delitos societarios en España, ver FARALDO CABANA, Patricia; MARTÍNEZ-BUJÁN PÉREZ, Carlos, Los delitos societarios presupuestos de su criminalización en España, Memoria de Tesis doctoral, La Coruña: Universidad de la Coruña, 1995, pp. 369-414.

${ }^{25}$ PIZARRO, Verónica, "Reconocimiento de intangibles y valoración de mercado; Influencia de las IFRS en Chile", Revista Contabilidad y sistemas, Vol. II (2007), pp. 3-4.

${ }^{26}$ Leyes parte del referido proceso de modernización son: la Ley 19.705 (20.12.2000) Regula las ofertas públicas de adquisición de acciones (Opas) y establece régimen de gobiernos corporativos, la Ley 20.382. (20.10.2009) Introduce perfeccionamientos a la normativa que regula los gobiernos corporativos de las empresas, Ley 20.190 (05.06.2007) Introduce adecuaciones tributarias e institucionales para el fomento de la industria de capital de riesgo y continua el proceso de modernización del mercado de capitales, la Ley 20.552 (17.12.2011) Moderniza y fomenta la competencia del sistema financiero, Ley 20.789 (06.11.2014), crea el consejo de estabilidad financiera, entre otras. Este proceso de modernización tiene sus orígenes en la dictadura, y se ha ido perfeccionando en los gobiernos democráticos posteriores a ella. En 1974 del Ministerio de planificación propuso 11 medidas para lograr la liberaIizaci6n y desarrollo del mercado financiero. La medida $11^{\circ}$ establecía la necesidad de asegurar la entrega del mayor número de informaci6n al inversionista en el contexto de la emisión de valores. Ver REINSTEIN, Andre y ROSENDE, Francisco, "Capitulo 9: La transformación financiera en Chile", en: LARRAÍN, Felipe y VERGARA, Rodrigo (Eds.), La transformación económica en Chile, $2^{\mathrm{a}}$ ed., Santiago: Publicaciones Centro de Estudio Públicos, 2001, p. 350.

${ }^{27}$ Cfr. informe sobre Chile de la OCDE "Phase 3 report on Implementing the OECD Anti-bribery convention in Chile" (marzo 2014), en particular ver $\mathrm{n}^{\circ} 7$.

${ }^{28}$ De los casos nombrados, en Inverlink existe condena en la denominada "arista tributaria", por delito contable tributario del art. 97 n 4 CT, ver SCS Rol 297-2009 (17.11.2010). "La Polar" cuenta con reciente sentencia definitiva (con recursos pendientes) en juicio abreviado, en que se condena a los autores, entre otros
} 
VARELA, Luis. "Delitos contables mercantiles en el Derecho penal económico chileno: Sistematización de su marco regulatorio, elementos comunes de sus tipos penales y desafíos pendientes".

\subsection{Noción y definición de Derecho de los estados financieros, y Derecho penal de los estados financieros en sentido amplio y estricto.}

Para definir que será entendido como Derecho penal de los estados financieros y delitos contables, es necesario abordar primero la noción de "Derecho de los estados financieros". En sentido amplio, se puede definir como el conjunto de normas y reglas jurídicas que regulan la rendición de cuentas, contabilidad y entrega de información del estado patrimonial, de ciertos sujetos de Derecho que participan en el tráfico jurídico económico, estableciendo deberes de confección, presentación, exhibición, publicidad, auditoría y cooperación con la fiscalización de las autoridades competentes ${ }^{29}$. En palabras más sencillas, el Derecho de la rendición de cuentas financieras en el más extenso sentido de su significado $^{30}$.

En cuanto a las nociones de Derecho (penal) de los estados financieros y de delito contable, se debe advertir primeramente que la palabra "contabilidad", las más de las veces, se entiende como como una sinécdoque, un pars pro toto que engloba a la de "estados financieros", siendo que conceptualmente es todo lo contrario ${ }^{31}$. Por ello, es preciso aclarar, que cuando se hable en este trabajo de Derecho (penal) de los estados financieros, se abarcará toda información financiera, sea ésta expresada o no de forma contable, y que se reservará, el nomen delitos contables, sólo para una clase específica de delitos, realizados por ocultación o manipulación de información contable, contenida en asientos contables, expresada en libros de contabilidad, o que dificulten su auditoría o fiscalización.

En este orden de ideas, se puede afirmar que el Derecho penal de los estados financieros es el conjunto de reglas penales y administrativas que sancionan la realización de conductas

delitos, por el sistema de "normalización de deuda" unilateral de clientes morosos, el que es calificado como una forma de esconder el verdadero estado patrimonial de la empresa en los balances, por lo cual se concluye que dichas prácticas se subsumen en los tipos de delitos contables mercantiles consagrados en la LMV que se verán infra, ver SJG Santiago $\left(8^{\circ}\right)$ en causa RUC 1100591305-7 (18.12.2015). Penta ha tenido su primer condenado en la persona del ex Senador Jovino Novoa, también por delito contable tributario, el imputado aceptó en juicio abreviado, el hecho que "registró y contabilizó como gastos: honorarios falsos, boletas de honorarios falsas", ver SJG Santiago $\left(8^{\circ}\right)$ en causa RIT 6873-2014. El caso Cascadas aún en proceso, se inició por una impugnación a los estados financieros de SQM en 2013 por parte de AFP de Chile y Moneda Asset, la SVS en procedimiento sancionatorio aplicó multas que luego fueron en parte revocadas respecto de los partícipes externos a SQM involucrados en el caso, ver SJC Santiago (29) causa Rol 21.500 (con recursos pendientes), con todo, la causa penal sigue en investigación, cuestión que también ocurre con el caso SQM, en que, si nos guiamos por la línea de acción de las diligencias de investigación, que han sido informado en los medios, los hechos tendrían también contenidos de delitos contables. No obstante lo anterior, la ley penal es aún insuficiente en materias de Derecho penal económico, y asimismo en materias de delitos contables, según veremos en las conclusiones. Sobre la insuficiencia de la ley penal chilena respecto de delitos económicos en general y con ilustración mediante casos ocurridos en los últimos lustros, cfr. WINTER, Jaime, "Derecho penal e impunidad empresarial en Chile", Revista de estudios de la justicia, n 19 (2012), pp. 119 y ss, para quien esta insuficiencia no sería fortuita.

${ }^{29}$ En un sentido parecido, SCHÜPPEN, Systematik und Auslegung des Bilanzstrafrechts, cit. nota ${ }^{\circ} 2, \mathrm{p} .15$.

${ }^{30}$ KANITZ, Friedrich von, Bilanzkunde für Juristen, 2. Aufl., München: Beck, 2010, pp. 15-17. En Alemania se denomina a esta área Rechnungslegungsrecht.

${ }^{31}$ HAGEDORN, Niklas, Bilanzstrafrecht im Lichte bilanzrechtlicher Reformen, Berlin: Berliner Wiss.-Verl., 2009 , p. 72. 
Polít. crim. Vol. 11, № 21 (Julio 2016), Art. 10, pp. 264-306.

[http://www.politicacriminal.cl/Vol_11/n_21/Vol11N21A10.pdf]

ilícitas en la entrega veraz, oportuna y transparente de información financiera-patrimonial o que obstaculicen los mecanismos de auditoría o fiscalización de dicha información ${ }^{32}$. Desde esta perspectiva se abarcan todos los delitos contables en sentido amplio y restringido, pero también la delincuencia referida al ocultamiento o entrega tendenciosa de cualquier otra información patrimonial de la organización o empresa, conste o no en libros contables, y que por ley deba ser puesta a disposición de forma trasparente y oportuna.

Luego, la noción de delitos contable en sentido amplio ${ }^{33}$ abarca todo delito propio del Derecho penal de los estados financieros en que la conducta típica recae sobre información patrimonial contenida en libros de contabilidad, abarcando tanto delitos contables mercantiles (delito contable en sentido restringido), como también delitos contables tributarios y delitos contables de la insolvencia (delito contable en sentido amplio) ${ }^{34}$.

Finalmente, la noción de delitos contables en sentido restringido ${ }^{35}$ abarca solamente a los delitos contables referidos a la denominada contabilidad mercantil, esto es, la regulada en el Código de Comercio (en adelante CCom) y leyes mercantiles respecto de personas jurídicas con fines comerciales ${ }^{36}$. En este sentido el delito contable involucra toda omisión de confección, ocultamiento, incorreción formal, falsedad, falta de completitud, inutilización de la información patrimonial, expresada en libros contables que deban ser exhibidos a socios, a terceros, a auditores, o a la autoridad reguladora, y esto, para esconder, en el sentido de ocultar o disimular, el real estado financiero-patrimonial de la empresa. En el presente artículo, abordaremos solamente los delitos contables del ámbito mercantil.

\subsection{Derecho penal y Derecho sancionador de los estados financieros.}

Conforme a la tendencia internacional, el Derecho penal económico chileno contiene tanto penas como sanciones administrativas para esta clase de ilícitos. Sin entrar en la discusión sobre la diferenciación entre ambas consecuencias jurídicas, y no obstante que en algunas legislaciones comparadas la diferenciación puede presentar dificultades al interprete en razón del solapamiento entre multas administrativas y penales, en el Derecho chileno, tanto doctrina como jurisprudencia afirman unánimemente la diferenciación entre éstas sobre la base de criterios formales bien delineados fundados en una relación sistemática entre los arts. 20 y 501 del Código penal (en adelante CP).

Dichos criterios serían, en primer lugar, uno de orden procesal, que atiende al órgano y a la naturaleza del procedimiento en que se aplica la sanción, en el caso de la "pena", un tribunal con competencia criminal, por medio de un procedimiento penal, y en el caso de la

\footnotetext{
${ }^{32}$ HAGEDORN, Bilanzstrafrecht, cit. nota $\mathrm{n}^{\circ}$ 31, p. 72; SORGENFREI, Ulrich, "Bilanz-Strafrecht und IFRS", PiR, (2006), p. 206 quien propone el nomen iuris Rechnungslegungsstrafrecht para esta categoría.

33 Bilanzstrafrecht in weiteren Sinn según la categoría acuñada por DANNECKER, Gerhard, "§ 28 Bilanzstrafrecht", en: ROTSCH, Thomas (Ed.), Criminal Compliance, Baden-Baden: Nomos, 2015, p. 181.

${ }^{34}$ HAGEDORN, Bilanzstrafrecht, cit. nota ${ }^{\circ} 31$, p. 73.

${ }^{35}$ Bilanzstrafrecht in engeren Sinn, según la categoría utilizada por DANNECKER, "§ 28 Bilanzstrafrecht", cit. nota $\mathrm{n}^{\circ} 33$ 179-180, antes, del mismo autor DANNECKER, Gerhard y BIERMANN, Jörg, "K. Steuerund Bilanzstrafrecht", en: BLUMERS, Wolfgang; FRICK, Jörg, et al. (Eds.), Betriebsprüfungshandbuch, München: C.H. Beck, 2008, p. K 1-3.

${ }^{36}$ DANNECKER/BIERMANN, "K. Steuer- und Bilanzstrafrecht", cit. nota $n^{\circ} 35$, p. 45.
} 
VARELA, Luis. "Delitos contables mercantiles en el Derecho penal económico chileno: Sistematización de su marco regulatorio, elementos comunes de sus tipos penales y desafíos pendientes".

sanción administrativa, un órgano de la administración del Estado en un procedimiento sancionatorio administrativo ${ }^{37}$. Luego, en segundo lugar, en cuanto a las multas, el CP estableció un límite para las multas en general y la posibilidad o no de convertibilidad en prisión. La primera regla del límite de la cuantía (Art. 501 CP) es ley común, por lo que se encuentra derogada tácitamente, tanto por criterios de especialidad como por criterios cronológicos ${ }^{38}$, en el caso que otra ley varíe las reglas descritas, debiéndose en todo caso atender al criterio procesal ya expresado.

Teniendo a la vista los dos criterios antes descritos, se puede afirmar, a propósito del régimen de sanciones y penas de los delitos contables, que en aquellos casos que la sanción establecida para el tipo sea aplicada por un órgano administrativo regulador; como la Superintendencia de valores y seguros (en adelante SVS), la Superintendencia de bancos e instituciones financieras (en adelante SBIF), la Superintendencia de insolvencia y reemprendimiento (en adelante SIR), o el Servicio de impuestos internos (en adelante SII) en caso de balances tributarios-, y cuando esto sea realizado en el contexto de un procedimiento sancionador definido en sus propias leyes orgánicas, se estará frente a un tipo sancionador. Por el contrario, cuando la conducta típica sea sancionada con una pena establecida en el CP o en una ley penal especial, por un tribunal con competencia criminal, y en un proceso penal, se estará frente a un tipo penal.

En este trabajo, trataremos sólo los tipos penales y cuando sea estrictamente necesario se hará referencia a los tipos sancionatorios.

\subsection{Alcance, carácter y función del Derecho penal de los estados financieros.}

A diferencia de Alemania, en donde las reglas penales de Bilanzstrafrecht del HGB alcanzan a todas las sociedades de capital $^{39}$, o en España, en donde el tipo penal de la falsedad en balances o documentos societarios cubre a toda entidad que participe de modo permanente en el mercado ${ }^{40}$, en el Derecho comercial chileno su alcance es restringido. Pues no obstante que el deber de confeccionar estados financieros mercantiles tiene por destinatario a todo comerciante (arts. 25 y ss. CCom), los tipos penales que contienen delitos contables mercantiles se limitan sólo a las Sociedades anónimas (en adelante SA) y

\footnotetext{
${ }^{37}$ POLITOFF, Sergio; MATUS, Jean Pierre, "§1. De las penas en general; Artículos 18 a 49", en: POLITOFF, Sergio; ORTIZ, Luis (Ed.), Texto y comentario del Código penal chileno, Santiago: Editorial Jurídica de Chile, 2002, p. 270; CURY, Enrique, Derecho Penal Parte General, $9^{a}$ ed., Santiago: Ediciones Universidad Católica de Chile, 2010, pp. 100-112.

${ }_{38}^{38}$ POLITOFF/MATUS, “\$1. De las penas en general”, cit. nota ${ }^{\circ} 37$, p. 271.

39 Esto es: sociedades anónimas $(A G)$, sociedades en comandita por acciones $(K G a A)$, sociedades de responsabilidad limitada $(\mathrm{GmbH})$, y por la regla norma amplificadora del $\$ 335$ b HGB a la mixtura de sociedades mercantiles colectivas y comanditas del §264a HGB conocidas como Kapitalgesellschaften und Co. Ver WITTIG, Petra, Wirtschaftsstrafrecht, 3. Aufl., München: Beck, 2014, p. 430; RANSIEK, "8. Teil Gesellschaftsrechtliche", cit. nota ${ }^{\circ} 23$, p. 966. Asimismo, el $§ 53$ Abs. 1 de la SEAG (versión alemana del Reglamento 2157/2001 CE Crea estatutos de la Sociedad europea -abreviado SE-), les hace aplicable esto tipos penales a la SE. Sobre Sociedades de capital en general en el contexto alemán ver WILHELM, Jan, Kapitalgeselschaftsrecht, 3. Aufl., Berlin: De Gruyter Recht, 2008, 17-72.

${ }^{40}$ Cfr. Art. 290 en relación al art. 297 CPE, ver FARALDO CABANA, Patricia, El delito societario de falsedad en documentos sociales, Valencia: Tirant lo Blanch, 2003, p. 99.
} 
Polít. crim. Vol. 11, No 21 (Julio 2016), Art. 10, pp. 264-306.

[http://www.politicacriminal.cl/Vol_11/n_21/Vol11N21A10.pdf]

a otras entidades especiales afines (arts. 2, 74, 75, 76 Ley de Sociedades anónimas en adelante LSA) sometidas a supervisión de la SVS (art. 3 Decreto ley SVS en adelante DLSVS) y a los bancos, que también necesariamente son SA (art. 27 y ss. Ley general de bancos en adelante LGBa). De ello es posible afirmar, que en Chile quedan excluidas de esta clase de delincuencia, la contabilidad de otras sociedades como las sociedades en comanditas, las sociedades por acciones (SpA) y las distintas clases de sociedades de personas, entre ellas la de responsabilidad limitada (en adelante SRL), como asimismo el comerciante individual, sea que ejerza su actividad por sí mismo o por medio de una empresa de responsabilidad limitada (EIRL). Corolario de lo anterior es que en el Derecho positivo chileno los delitos contables mercantiles se supeditan casi exclusivamente al funcionamiento del mercado societario de capitales, y no al funcionamiento del tráfico económico en general ${ }^{41}$.

Finalmente, en lo referente a su función, estaría dada por los fines propios de la contabilidad regulada jurídicamente, cuestión que se verá en el apartado 2.3.

\subsection{Modelos en Derecho comparado.}

En Derecho comparado es posible distinguir dos grandes modelos de incriminación para esta clase de delitos, uno de tipo de casuístico -legislación alemana, francesa y de los países anglosajones- y un modelo penal conceptual unitario -legislación española e italiana- ${ }^{42}$.

El sistema de tipo casuístico, fragmenta los tipos penales según la figura de la sociedad y la tipología de las informaciones financieras que serán típicamente relevantes, generando diversos tipos penales según las concretas formas de la sociedad y del contexto en que éstas operan $^{43}$.

\footnotetext{
${ }^{41}$ Aunque no se abordará en este artículo, se debe precisar que en el caso de los delitos contables tributarios y asimismo en los de la insolvencia, el alcance es más amplio, alcanzando en el primer caso a todo contribuyente o su representante (art. $8 \mathrm{~N}^{\circ} 5$ y 6 Código Tributario en adelante CT -se han tenido a la vista las reformas introducidas por el art. 3 de Ley Ley 20.899 de 08.02.2016 a este cuerpo legal) y en el segundo de los casos, al deudor - $\mathrm{O}$ quién represente a tal- en estado de insolvencia (art. $2 \mathrm{~N}^{\circ} 12$ Ley Reorganización y Liquidación de Activos de Empresas y Personas en adelante LRLEP). PUGA VIAL, Juan Esteban, Derecho concursal delitos de la quiebra, $2^{\mathrm{a}}$ ed., Santiago: Editorial Jurídica de Chile, 2002, p. 113. Aunque la obra, citada aborda los delitos de la insolvencia, en su configuración anterior a la entrada en vigencia de la actual ley de insolvencia de 2014, es tal vez la monografía más completa sobre el tema y que conserva su valor dogmático para las nuevas figuras, en varios aspectos, análogas. También desde 2011 las reglas de rendición de cuentas y deber legal de confeccionar contabilidad conforme normas de aceptación general se extendió a las personas jurídicas de Derecho privado (corporaciones y fundaciones) en virtud de la Ley 20.500 (16.02.2011) Sobre asociaciones y participación ciudadana en la gestión pública, que introdujo modificaciones a diversos cuerpos legales, entre ellos al Título XXXIII del Libro I del Código Civil (en adelante CC)

${ }^{42}$ FOFFANI, Luigi "Delitos concursales y societarios", en: TIEDEMANN, Klaus; NIETO MARTÍN, Adan (Eds.), Eurodelitos: el derecho penal económico en la Unión Europea, Cuenca: Ediciones de la Universidad de Castilla-La Mancha, 2005, p. 104.

${ }^{43}$ En Alemania por ejemplo se distinguen variados tipos penales que establecen delitos contables. Uno de aplicación general en las Sociedades de capital en el §331 y ss. HGB, uno específico subsidiario para las SA en el $\S 400$ Abs. 1 Nr. 1 de la Ley de sociedades anónimas (AktG), otro subsidiario para las SLR en el §82 Abs. 2 Nr. 2 de la ley que regula dichas sociedades (GmbHG), y otros en contextos específicos en los cuales
} 
VARELA, Luis. "Delitos contables mercantiles en el Derecho penal económico chileno: Sistematización de su marco regulatorio, elementos comunes de sus tipos penales y desafíos pendientes".

El sistema de tipo conceptual o unitario, concentra en un solo tipo penal todas las conductas de manipulación u ocultamiento de estados financieros, sea porque lo regula como una especie de delito especial referido al ejercicio del gobierno corporativo -denominados delito societario en España-, sea porque el tipo, normalmente uno de falsedad documental en instrumento privado, o uno de estafa, permiten subsumir las conductas catalogadas como delitos contables en éstos ${ }^{44}$.

El sistema chileno puede ser clasificado dentro del denominado sistema casuístico, pues sus delitos contables se encuentran repartidos en distintas leyes especiales, y referidas a distintos contextos y características -sujetos activos o información financiera concreta-, aunque no debe ser descartado a priori, que ciertas conductas puedan ser subsumidas en la estafa o en el tipo de falsedad documental del CP. En lo que respecta a los delitos contables mercantiles, estos se encuentran en la LSA, la Ley de mercado de valores (en adelante LMV) y LGBa. Con todo, para entender el contenido de este modelo es necesario primeramente analizar los puntos más importantes del marco regulatorio de los estados financieros contables presentes en la legislación interna.

\section{Marco regulatorio sobre confección, exhibición y fiscalización de estados financieros.}

\subsection{Fuentes formales; sistemática propuesta.}

Las fuentes formales de los estados financieros mercantiles en el derecho chileno son: legales, administrativas y reglas técnicas jurídicamente reguladas. Para facilitar la exposición sistemática, dentro de las fuentes legales se subdistinguirá, entre las referidas al deber y forma de confección, a los deberes de presentación, a su exhibición-publicidad, y finalmente a su control por medio de auditoría y fiscalización. Además, se hará una breve mención de la regulación de los estados financieros con fines tributarios, que, aunque en la práctica, se solapan con los mercantiles, son tratados de forma diferenciada por el legislador. $^{45}$

\subsubsection{Fuentes legales de estados financieros mercantiles.}

a) Deber y forma de confección.

La legislación común sobre estados financieros mercantiles se encuentra contenida en el $\mathrm{CC}$, en cuanto al deber genérico del administrador de una sociedad de rendir cuenta de su administración (art. 2080 CC) y el CCom, Libro I, Título II § 2, que regula en sus aspectos más generales la contabilidad mercantil. Estas normas establecen el deber de todo

la presentación de estados financieros es exigida como son los $\$ 17$ PublG, §14, §147 Abs. 2 Nr. 1 GenG, §313 Abs. 1 Nr. 1 UmwG. Asimismo, el §265b del Código penal alemán (en adelante StGB) establece un tipo referido a la denominada estafa crediticia por medio de presentación de estados financieros fraudulentos.

${ }^{44}$ España tiene concentrados sus delitos contables en el CPE, en el art. 290, que contempla un tipo penal de amplio alcance.

${ }^{45}$ PUGA VIAL, Juan Esteban, La sociedad anónima y otras sociedades por acciones en el derecho chileno y comparado, Santiago: Editorial Jurídica de Chile, 2011, p. 461. 
Polít. crim. Vol. 11, № 21 (Julio 2016), Art. 10, pp. 264-306.

[http://www.politicacriminal.cl/Vol_11/n_21/Vol11N21A10.pdf]

comerciante (art. $3 \mathrm{CCom}$ ) de llevar contabilidad (art. 25 inc. $1^{\circ} \mathrm{CCom}$ ), las reglas básicas sobre su confección, por ejemplo; los libros que se deben llevar (art. $25 \mathrm{n}^{\circ} 1$ al 4 CCom), su concreta forma (Art. 26, 27, 28, 29, 30, CCom), el momento desde que deben ser llevados al abrir su giro-, las reglas esenciales sobre el "balance general anual" (art. 29 inc. $2^{\circ}$ CCom) y el deber de mantención de los libros -hasta que se ejerza el giro- (art. 44 CCom). El CCom también contempla prohibiciones expresas de "alterar" asientos contables, y otras que tienen por fin resguardar la "veracidad" de éstos y protegerlos de manipulaciones (art. $31 \mathrm{CCom})^{46}$, como asimismo sanciones civiles, en cuanto a sus efectos probatorios, cuando no sean observadas dichas prohibiciones (art. 34 y ss. CCom). Todas estas normas y reglas legales de contabilidad mercantil son aplicables a todo comerciante individual y tipo de sociedad comercial existente en el Derecho chileno, sea ésta de personas o de capital ${ }^{47}$.

A continuación, existen normas y reglas especiales para las Sociedades de capital en la LSA y reglas específicas para las SA que participan del mercado bursátil en la LMV. La primera añadió deberes específicos de contabilidad en su Título VII "Del Balance de otros Estados y Registros Financieros y de la distribución de las utilidades", en el cual se contempla el deber de llevar estados financieros conforme a los principios de aceptación general (arts. 73 LSA), de forma anual -al 31 de diciembre de cada año- (art 74 inc. $1^{\circ}$ LSA), el deber del directorio de presentar a la junta de accionistas una memoria junto al balance, y un estado de ganancias y pérdidas más los informes de auditoría o de los inspectores de cuenta - en su caso- y el deber de "claridad" de la referida información contable (art. 74 inc. $2^{\circ}$ LSA) ${ }^{48}$. Finalmente, respecto de los consorcios, se consagra la regla de que éstos deben llevar estados financieros consolidados (art. 90 inc. $2^{\circ}$ LSA $)^{49}$.

Las reglas específicas para las SA abiertas que participan en el mercado bursátil y que se consagran en la LMV serán vistas en los apartados que siguen.

\footnotetext{
${ }^{46}$ La redacción original propuesta en el primer borrador de Código de Comercio chileno propuesto por Ocampo establecía una frase final que rezaba: "El comerciante sufrirá también una multa de 90 a 300 pesos aplicable al fisco. 1. Si el defecto o alteración del libro o libros hubiera dado lugar a la suplantación de una partida, falsa en todo o en parte, el Tribunal de Comercio dará aviso instruido al juez competente para que proceda criminalmente contra el autor y cómplice de la falsificación" (la cursiva es nuestra). Y luego proponía el mismo Ocampo un artículo que establecía una multa a favor del fisco de 300 a 1500 pesos en caso de que el comerciante no llevase u ocultase los libros de contabilidad antes enumerados. El segundo borrador propuesto por Ocampo mantiene la redacción del primero, pero intercala un artículo en el que establece que las multas establecidas deberán ser asumidas por el responsable de la teneduría de libros, ver OCAMPO, José Gabriel; BRAHM GARCÍA, Enrique (Eds.), José Gabriel Ocampo y la codificación comercial chilena los primeros borradores del proyecto de código de comercio : tomo I, Santiago: Editorial Universidad de Los Andes, 2000, pp. 65-67 y pp. 146-147 respectivamente.

${ }^{47}$ PALMA, Gabriel, Derecho Comercial, T. I, Santiago: Talleres gráficos Artulfo, 1935, pp. 117-118 y 127 y ss. SANDOVAL, Ricardo, Derecho Comercial, Vol. I, T. II, $7^{\text {a }}$ ed., Santiago: Editorial Jurídica de Chile, 2009, pp. 90 y ss. Para este autor el fundamento y alcance de este deber sería triple: es una obligación establecida en el interés de la propia gestión del comerciante, posibilita que los terceros conozcan la situación de la empresa y finalmente es un medio necesario para calificar la quiebra del deudor.

48 PUELMA, Alvaro, Sociedades, T. II, $3^{\text {a }}$ ed., Santiago: Editorial Jurídica de Chile, 2001, pp. $677-687$. ALCALDE, Enrique, La responsabilidad de los directores de sociedades anónimas; responsabilidad civil y penal administrativa, Santiago: Ediciones UC, 2013, pp. 149 y ss.

${ }^{49}$ PUELMA, Sociedades, cit. nota ${ }^{\circ} 48$, p. 689.
} 
VARELA, Luis. "Delitos contables mercantiles en el Derecho penal económico chileno: Sistematización de su marco regulatorio, elementos comunes de sus tipos penales y desafíos pendientes".

\section{b) Deber de exhibición, presentación y publicidad.}

Existe una serie de normas y reglas legales referidas a la exhibición de los estados financieros a sujetos que participan "desde adentro" en las actividades de la sociedad ${ }^{50}$, tales como accionistas, trabajadores, personas o sociedades que se encuentran en una relación jurídico-económica actual con ésta (por ej. tenedores de bonos). Luego son también identificables un conjunto de reglas referidas a la presentación ante la autoridad reguladora $^{51}$ y finalmente reglas referidas a la publicidad de la información a terceros "externos" de la sociedad, como potenciales inversores o simplemente el público general ${ }^{52}$. Respecto del deber de exhibir los estados financieros a accionistas, la LSA reguló expresamente esta exhibición ${ }^{53}$, distinguiendo reglas diferentes para las SA abiertas y para las cerradas (art. 2 LSA). En el caso de las primeras, se debe colocar a disposición de los accionistas inscritos una copia del balance y de la memoria antes de la primera convocatoria a junta ordinaria (art. 75 inc. $1^{\circ}$ LSA), mientras que, en el caso de las segundas, el envío de éstos será hecho sólo a los accionistas que así lo soliciten (art. 75 inc. $2^{\circ}$ LSA). Pese dichas reglas, la memoria, balance, inventario, actas, libros y los informes de los auditores externos y, en su caso, de los inspectores de cuentas, debe estar a disposición de todo accionista de SA abierta o cerrada para su examen, en la oficina de la administración de la sociedad, durante los quince días anteriores a la celebración de la junta de accionistas, pudiendo éstos sólo examinar dichos documentos en el plazo señalado (art. 54 LSA). Esta entrega de información es capital para que luego los accionistas puedan ejercer su facultad de aprobar o rechazar los estados financieros de la sociedad (art. 77 LSA), cuestión no menor, pues de rechazarse éstos por segunda vez, el directorio quedará revocado de pleno derecho (art. 77 inc. $3^{\circ}$ LSA), lo que causa la inhabilidad de los directores que aprobaron dicho balance para ser reelegidos como titulares o suplentes en el directorio de la misma sociedad por el período completo siguiente (art. 77 Reglamento de la LSA en adelante Re-LSA).

Por su parte, respecto de los consorcios, se establece que en la memoria anual, el directorio deberá señalar las inversiones de la sociedad en sociedades coligadas o filiales y las modificaciones ocurridas en ellas durante el ejercicio, debiendo dar a conocer a los accionistas, los balances de dichas empresas y una memoria explicativa de sus negocios (art 90 LSA $)^{54}$.

En cuanto al deber de exhibición a los trabajadores de la empresa de la SA, el CCom y la LSA guardan silencio, es el Código del Trabajo (en adelante CTr) el que dispuso el deber de toda empresa de entregar los balances - de al menos dos años atrás- a los trabajadores que deseen iniciar una negociación colectiva, con el fin de preparar el proyecto de contrato colectivo (art $315 \mathrm{CTr}$ ). En este sentido, los trabajadores pueden, para efectos de determinar

\footnotetext{
${ }^{50}$ PUELMA, Sociedades, cit. nota $\mathrm{n}^{\circ} 48$, p. 677.

${ }^{51} \mathrm{La}$ SVS en caso de SA abiertas a la SBIF en el caso de Bancos e instituciones financieras.

${ }^{52}$ PUGA VIAL, La sociedad anónima, cit. nota ${ }^{\circ}$ 45, pp. 413-415

${ }^{53}$ PUGA VIAL, La sociedad anónima, cit. nota $\mathrm{n}^{\circ} 45$, pp. 406-410.

${ }^{54}$ PUELMA, Sociedades, cit. nota ${ }^{\circ} 48$, p. 679.
} 
Polít. crim. Vol. 11, № 21 (Julio 2016), Art. 10, pp. 264-306.

[http://www.politicacriminal.cl/Vol_11/n_21/Vol11N21A10.pdf]

el monto de las gratificaciones, pedir al SII que le proporciones balances e información financiera certificada para el cálculo del monto de aquella (art. $49 \mathrm{CTr}$ ).

Finalmente, en lo que se refiere a la exhibición de información financiera a personas o sociedades que encuentran en una relación actual jurídico-económica, el CCom contempló como regla general que la manifestación general de libros contables no pueda ser ordenada por los tribunales -ni de oficio ni a instancia de partes-, salvo para ciertos casos específicos (art. 42 CCom). Luego la LSA no estableció mayores reglas especiales, siendo la LMV, la que en su Título III De la información continua y reservada, consagró el deber de entregar información relevante a terceros (arts. 10 y ss.), entre las que figuran los estados financieros. Las mismas reglas, pero con ciertas variaciones específicas en razón del área regulada, se introdujeron luego para:

- Consorcios y sociedades controladoras a los cuales se les obliga entregar información consolidada a las sociedades que forman parte del grupo empresarial (art. 101 LMV).

- SA que emiten valores, las que deben de informar su situación jurídica, económica y financiera al momento de emitir un "valor" (art. 8 LMV), y entregar información específica, lo que es regulado por normas de carácter general dictadas por la SVS como veremos más adelante $\left(\mathrm{N}^{\circ} 30 \mathrm{Sec}\right.$. IV de la Norma de carácter general SVS en adelante NGC-SVS). En este contexto, la ley agrega que toda entidad inscrita en el registro de valores tendrá el deber de entregar información a la SVS y al público cuando ley o ésta lo requiera. Información que debe ser veraz, suficiente, y oportuna, y esto cuando el negocio ocurra o cuando llegue a concretarse (art. 10 inc. $2^{\circ}$ LMV) ${ }^{55}$. Reglas análogas existen para la emisión de títulos de deuda a corto plazo (Artículos 131 letra a, 134, 144, 149 LMV), valores extranjeros (art. 192 LMV), y las sociedades administradoras de fondos ${ }^{56}$.

- La oferta pública de adquisición (de acciones) -denominadas OPAs en Chile-, poseen también reglas especiales sobre información financiera. Se tiene que, ante todo, publicar un aviso informando la oferta, el que debe "contener los antecedentes esenciales para su acertada inteligencia, que la Superintendencia determinará mediante norma de carácter general" (art. 202 LMV y NCG $\mathrm{N}^{\circ} 30$ SVS). Luego se debe confeccionar un prospecto informativo para los interesados, el cual debe contener una descripción financiera y jurídica de los negocios del oferente o de sus controladores, y las demás que disponga SVS (art. 205 letras a, k, LMV y NCG SVS $\mathrm{N}^{\circ} 30$ Sec. I) ${ }^{57}$. Toda esta información debe entregarse al

\footnotetext{
55 Estas reglas generales, válidas para las entidades que emiten valores, son complementadas por reglas especiales para la emisión de títulos de deuda a largo plazo, las que requieren para ser autorizada de información jurídica y económica previa confeccionada por el emisor- (art. 104 inc. $1^{\circ}$ y $2^{\circ}$ letra a LMV), contemplando el derecho de los representantes de tenedores de bonos para solicitar al emisor o auditores externos sus estados financieros y el deber de éstos de dárselos correctamente (art. 108 LMV). Finalmente, el emisor del bono deberá entregar al representante de tenedores la misma información que dio a la SVS (art. 110 LMV), debiendo llevar contabilidad aparte para los referidos bonos (art. 114 LMV).

${ }^{56}$ Con la entrada en vigencia de la Ley 20.712 (07.01.2014) de Administración de fondos de terceros y carteras individuales, este tema se ha sacado de la LMV.

${ }^{57}$ Junto a esto los directores de la SA deben emitir individualmente un informe con su opinión fundada acerca de la conveniencia de la oferta para accionistas y su relación con el controlador de la sociedad, con el
} 
VARELA, Luis. "Delitos contables mercantiles en el Derecho penal económico chileno: Sistematización de su marco regulatorio, elementos comunes de sus tipos penales y desafíos pendientes".

público, a la SVS, a las bolsas de valores, al oferente y al administrador u organizador de la oferta (art. 207 letra c LMV). La ley autoriza a la SVS para pedir más información complementaria si lo estima conveniente (art. 214 LMV). Finalmente se aplican las mismas reglas a las $O P A s$ convertibles en extranjeras (art. $218 \mathrm{LMV})^{58}$.

Por último, en cuanto al deber de publicidad o información a terceros y al público en general, aunque no es un deber general para las sociedades de personas y SA cerradas, lo es para las SA abiertas, las cuales deben publicar información en internet sobre sus estados financieros (art. 76 LSA), teniendo la SVS la atribución de requerir de fiscalizados que proporcionen, información veraz, suficiente y oportuna al público sobre su situación jurídica, económica y financiera (art. 4 letra g DL-SVS) ${ }^{59}$.

\section{c) Auditoria y fiscalización.}

Como se indicó, conforme al CCom, ni los propios tribunales pueden controlar de oficio o a petición de parte los estados financieros. Esta regla, sumamente restrictiva, cambia por completo cuando se trata de la LSA, pues ésta ha consagrado dos formas de control, uno interno y otro externo ${ }^{60}$. El primero, es facultativo para la SA cerrada, y es realizada por inspectores de cuentas nombrados por la junta ordinaria de accionistas. Su misión -entre otras actividades de control- es la de examinar los estados financieros, e informar a la junta sobre éstos (art. 51 LSA) ${ }^{61}$. El segundo sistema de control, es el realizado por una empresa de auditoría externa. La LSA establece que este es un sistema obligatorio para las SA abiertas y luego se remite a las reglas sobre el particular presente en la LMV (arts. 52 LSA). Este reenvío se refiere al Título XXVIII de la LMV titulado De las empresas de auditoría externa, el cual establece el marco legal para esta actividad, definiendo primeramente qué es una empresa de auditoría externa y cuáles son sus funciones principales (art. $239 \mathrm{LMV}{ }^{62}$, en el caso de estados financieros, su examen y expresión de opinión profesional e independiente, conforme a las normas de auditoría de general aceptación y las instrucciones que imparta la SVS (Circular-SVS N ${ }^{\circ} 478$ 01.02.1985 texto refundido, en adelante toda circular será abreviada CIR), debiendo además informar sobre las deficiencias de las prácticas contables, sistemas administrativos y de auditoría interna, como asimismo el cumplimiento de las obligaciones tributarias de la sociedad y la de sus filiales incluidas en la respectiva auditoría (art. 246 LMV).

Por último, en cuanto a la fiscalización realizada por el ente regulador, lo primero que se debe recalcar es que por regla general los estados financieros mercantiles no se encuentran sometidos a fiscalización de ninguna especie. Las SA abiertas y otras entidades que participan en el mercado bursátil de capitales son las únicas que se encuentran bajo la

oferente, e interés que pudiere tener en la operación (art. 10 inc. $2^{\circ}$ LMV y las NCG-SVS N 30 de 1989 y N ${ }^{\circ}$ 129 de 2002).

${ }^{58}$ PUGA VIAL, La sociedad anónima, cit. nota $\mathrm{n}^{\circ} 45$, pp. 210-231

${ }^{59}$ PUGA VIAL, La sociedad anónima, cit. nota n ${ }^{\circ} 45$, pp. 413-415.

${ }^{60}$ PUELMA, Sociedades, cit. nota $\mathrm{n}^{\circ} 48$, p. 645.

${ }^{61}$ PUGA VIAL, La sociedad anónima, cit. nota $\mathrm{n}^{\circ}$ 45, pp. 534-535

${ }^{62}$ BERNET, Manuel, "El gobierno de las sociedades abiertas", Revista de Derecho n ${ }^{\circ} 16$ (2004), p. 33. La auditoría externa sería un fundamento teórico básico de la doctrina de los Corporate Governance. 
Polít. crim. Vol. 11, № 21 (Julio 2016), Art. 10, pp. 264-306.

[http://www.politicacriminal.cl/Vol_11/n_21/Vol11N21A10.pdf]

súper-vigilancia de la SVS (art. 3 DL-SVS), la que tiene una serie de atribuciones referida a sus estados financieros, como las de examinar los libros, cuentas, archivos y documentos, requerir la información que juzgue necesaria para su información, como asimismo el exigir de éstos la ejecución y presentación de balances y estados financieros en las fechas que estime convenientes, debiendo los fiscalizados tener disponible permanentemente la referida información para su examen por parte del ente regulador, lo cual se extiende a la información financiera de su consorcio (art. 4 letra d DL-SVS).

\subsubsection{Breve referencia a las fuentes legales de estados financieros para efectos tributarios.}

La contabilidad para efectos tributarios, cuya finalidad es determinar el monto imponible de los contribuyentes, está definida en el CT (art 17 inc. $5^{\circ} \mathrm{CT}$ ). Este cuerpo legal contempla en primer lugar el deber de todo contribuyente (art $8 \mathrm{~N}^{\circ} 5 \mathrm{CT}$ ) de llevar contabilidad tributaria conforme a las prácticas contables adecuadas (art. 16 inc. $1^{\circ} \mathrm{CT}$ ), estableciendo el principio general de "quien debe declarar renta debe llevar contabilidad" (arts. 21 y 29 CT), sea esta completa o simplificada, o pequeños comerciantes minoristas quienes podrán verse eximidos de llevar contabilidad (art. $23 \mathrm{CT}$ ).

Luego respecto del deber de presentación de la contabilidad tributaria, todo contribuyente, en el contexto del proceso de declaración anual de renta (art. 21, 33, 35 CT), debe exhibir sus estados financieros contenidos en sus libros contables, los cuales deben ser presentados con firma de un contador (art. 35 inc. $1^{\circ} \mathrm{CT}$ ).

Finalmente, en lo que respecta a su fiscalización, el SII es la autoridad competente, y en ejercicio de sus atribuciones, puede revisar la contabilidad realizada en libros materiales (art. 59 letra d CT), como la realizada por medios electrónicos o aplicaciones informáticas (art. 60 bis y 60 ter CT). El Director del SII podrá siempre ordenar auditorías a éstos medios (art. 60 quater).

La relevancia que la contabilidad tributaria tiene para efectos de los delitos contables mercantiles está dada por el hecho de que es la propia ley la que consagra un sistema de coordinación e intercambio de información entre el SII, la SVS, y la SBIF respecto de la información financiera, y esto, con la finalidad de facilitar sus respectivas fiscalizaciones $\left(\operatorname{art} 84\right.$ bis CT) ${ }^{63}$.

\subsubsection{Fuentes administrativas.}

El Re-LSA, las NCG, circulares y oficios de la SVS y otros órganos reguladores constituyen el cuerpo de normas administrativas que regulan en detalle varios de los aspectos del marco legal. Uno de los reglamentos más importantes en este sentido es el ReLSA, el cual estableció reglas específicas sobre la facultad de las SA cerradas - no sujetas a la SVS- de decidir el sistema de control interno de las finanzas que sus accionistas estimen conveniente (art 90 Re-LSA). Esta regla se ve afectada en cuanto a las SA cerradas

\footnotetext{
${ }^{63}$ Sobre el sentido jurídico de los balances tributarios, cfr. WEBER-GRELLET, Heinrich, Bilanzsteuerrecht, 13. Aufl., Münster: Alpmann Schmidt, 2015, p. 30 y p. 48 en cuanto a la relación con entre balance comercial y tributario.
} 
VARELA, Luis. "Delitos contables mercantiles en el Derecho penal económico chileno: Sistematización de su marco regulatorio, elementos comunes de sus tipos penales y desafíos pendientes".

sometidas a la SVS, pues requerirán siempre auditoría externa (art. 91 Re-LSA). El reglamento regula también la existencia de un registro de inspectores de cuentas y empresas auditoras externas (art 92 y 93 Re-LSA).

En cuanto al conjunto de reglas dictadas por entes reguladores con facultades legiferantes, destacan por su importancia las denominadas NCG de la SVS, en este grupo la NCG-SVS $\mathrm{N}^{\circ} 30$ (10.11.1989) -con sus respectivas modificaciones-, ha venido a regular en detalle la información sobre estados financieros que ciertas entidades sometidas a control de dicha Superintendencia deben entregar. De suma importancia para nuestro tema son también la NCG N 117 (20.04.2001) -y sus respectivas modificaciones-, que reguló la entrega de información a través de internet y medios electrónicos, y las circulares y oficios de las SVS que introdujeron en Chile el sistema contable de los International financial reporting standard (en adelante IFRS).

\subsubsection{Reglas técnicas referidas a la contabilidad jurídicamente reconocida.}

Los denominados "principios contables comúnmente aceptados", en inglés "Generally accepted accounting principles" (GAAP), en alemán "Grundsätze ordnungsmäßiger Buchführung” (GoB), son las reglas técnicas de la profesión contable y de la auditoría financiera. Como todo conjunto de reglas de ejercicio de una profesión u oficio, han sido establecidas en razón de su general aceptación por quienes profesan el respectivo arte. Como ocurre con otras actividades de gran significado social, el Derecho ha elevado estos estándares a norma jurídica, de forma directa o por remisión, con lo cual su observancia no involucra ya una mera necesidad práctica, sino que también involucra un deber jurídico ${ }^{64}$.

En Chile conviven actualmente dos sistemas de reglas técnicas para la confección de los estados financieros, la antigua norma chilena de contabilidad, denominada en nuestro medio como "principios de contabilidad generalmente aceptados" (en adelante PCGA) y junto a ésta, desde 2006, el nuevo sistema IFRS.

En lo que se refiere a la regla chilena, ésta se configura dentro del marco legal establecido por la Ley 13.011 del Colegio de contadores de Chile (29.09.1958), que le reconoció al Consejo general de dicho gremio la atribución de dictar normas relativas al ejercicio profesional de la contabilidad (art. 13 letra g de la Ley de contadores de Chile en adelante LCC). Esta atribución fue ejercida a través de la dictación de Boletines Técnicos (en adelante BT), entre los que destacan; el no 1 "Teoría Básica de la Contabilidad" (1973), y el no 56 "Principios y Normas de Contabilidad" (1997), como también las "Normas de Auditoría Generalmente Aceptadas" (en adelante NAGAS) no 22 (1997), no 23 (1997), nº

\footnotetext{
${ }^{64}$ HOHL, Patrick, Private Standardsetzung im Gesellschafts- und Bilanzrecht: verfassungsrechtliche Grenzen kooperativer Standardsetzung im europäischen Mehrebenensystem an den Beispielen des Deutschen Corporate Governance Kodexes und der International Financial Reporting Standards, Berlin: Duncker \& Humblot, 2007, p. 146. En síntesis, se deben entender a las reglas contables como soft law. Una relación entre el antiguo sistema GAAP y el nuevo IFRS, en: MEYER, Claus, Bilanzierung nach Handels- und Steuerrecht : unter Einschluss der Konzernrechnungslegung und der internationalen Rechnungslegung ; Kontrollfragen, Aufgaben und Lösungen, Lernprogramm, 26. Aufl., Herne: NWB, 2015, pp. 291 y ss.
} 
Polít. crim. Vol. 11, № 21 (Julio 2016), Art. 10, pp. 264-306.

[http://www.politicacriminal.cl/Vol_11/n_21/Vol11N21A10.pdf]

25 (1997). ${ }^{65}$ Todo este corpus conformó la señalada norma chilena de contabilidad al cual

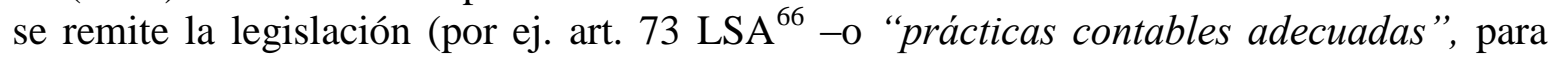
efectos tributarios art. 16 inc. $1^{\circ} \mathrm{CT}-$ ) y la norma chilena de auditoría, las que a su vez han sido desarrolladas sobre bases técnicas, y considerando la antigua noma International accounting standards (los IAS o NIC -en español- pre IFRS) con adaptaciones a la realidad nacional ${ }^{67}$. Su importancia radica en que gran parte de las empresas chilenas la siguen usando tanto para efectos mercantiles como para efectos tributarios ${ }^{68}$.

Por su parte, el sistema IFRS ${ }^{69}$ comenzó a ser introducido en el espacio chileno desde 2006 por medio de oficios y circulares de la $\mathrm{SVS}^{70}$. Dicha institución ha ejecutado este proceso en cumplimiento del compromiso del Estado de Chile para con la OCDE de impulsar la adopción de este nuevo sistema internacional de contabilidad, definiendo como fecha de inicio para su aplicación obligatoria; el 01.01.2009 para las SA abiertas y el 01.01.2013 para las SA cerradas ${ }^{71}$.

No obstante que a la fecha cada vez más empresas bajo control de la SVS utilizan este sistema para confeccionar sus estados financieros, no deja de llamar la atención, que un aspecto tan importante no sea abordado por el legislador, y por el contrario, sea dejado exclusivamente en manos de un ente administrativo, que lo regula además con total discrecionalidad $^{72}$. En efecto, por ejemplo, en el marco regulatorio de la UE, el nuevo

${ }^{65}$ Otros BT de relevancia son los del Colegio de Contadores de Chile AG: BT n 6 "Contabilidad de Contingencias" (1978), BT no 15 "Tratamiento de Cambios Contables" (1979), BT n 50 "Estado de Flujo de Efectivo" (1995), las normas de Auditoría Generalmente Aceptada BT no 22 (1997), BT no 23 (1997), BT nº 25 (1997).

${ }^{66}$ Ver BT $n^{\circ} 56$ del Colegio de Contadores de Chile AG.

${ }^{67}$ Sobre correspondencia entre el sistema internacional y el nacional pre IFRS ver BRAVO HERRERA, Fernando, Análisis de estados financieros. Textos y casos, Santiago: Editorial Jurídica de Chile, 2011, pp. 2734.

${ }^{68}$ El calendario de implementación del sistema contable IFRS para entidades reguladas por la SVS se encuentra disponible en http://www.svs.cl/portal/principal/605/articles-13678_doc_pdf.pdf [consultado por última vez 15.12.2015]. Al año 2011 el $69 \%$ de los entes regulados por la SVS utilizaban sistema IFRS. Ver http://www.economiaynegocios.cl/especiales/Especial_IFRS/cifras.html [consultado por última vez 15.12.2015].

${ }^{69}$ PELLENS, Bernhard, Internationale Rechnungslegung: IFRS 1 bis 8, IAS 1 bis 41, IFRIC-Interpretationen, Standardentwürfe ; mit Beispielen, Aufgaben und Fallstudie, Stuttgart: Schäffer-Poeschel, 2008, pp. 79-106, este nuevo estándar internacional, que tiene su origen en la gran reforma en 2001 provocó el reemplazo del IASC por el nuevo IASB, y la sustitución como estándar internacional de las antiguas IAS, tiene por finalidad manifiesta la de generar un estándar de contabilidad utilizable a nivel global, y con esto reducir malentendidos entorno a la preparación de estados financieros, mejorar el análisis de los mismos y aumentar el nivel de calidad de la contabilidad.

70 Oficio CIR-SVS N 368 (16.10.2006) y una larga lista de oficios complementarios disponibles en http://www.svs.cl/portal/principal/605/w3-propertyvalue-18641.html [consultado por última vez 15.12.2015].

71 JARA, Luis; CONTRERAS, Harold, "Adopción de IFRS en empresas chilenas. Énfasis en los efectos cuantitativos sobre la información financiera", Capic Review (2010), pp. 14-15.

${ }^{72}$ Paradigmático es el caso del lobby de la Sociedad de fomento fabril, que solicitó a la SVS el ajuste de cambio de tasa de impuesto a la renta no fuera reconocido en el resultado del ejercicio, sino en patrimonio. Al día siguiente de la solicitud (16.10.2014), la SVS -a través de un escueto Oficio CIR-SVS $\mathrm{n}^{\circ} 856$ (17.10.2014), que contiene un párrafo de sólo 6 líneas carentes de fundamentos técnicos, instruyó a empresas fiscalizadas a no aplicar el criterio dispuesto en la norma IFRS n ${ }^{\circ} 12$. Ver columna de JARA, Luis, "Chile 
VARELA, Luis. "Delitos contables mercantiles en el Derecho penal económico chileno: Sistematización de su marco regulatorio, elementos comunes de sus tipos penales y desafíos pendientes".

sistema contable fue adoptado por sendos Reglamentos europeos (en adelante RE), es decir, legislación comunitaria (RE $\mathrm{N}^{\circ} 1126-2008$ y textos complementarios), y en muchos de los países miembros, introducidos además por ley (en Alemania por la BilMog de 29.05.2009).

En Chile, esto no ha sido siquiera regulado por NCG autorizadas por ley, sino que por meros oficios ( $i$ !), lo cual podría abrir las puertas a la arbitrariedad ${ }^{73}$. Con todo, y hechas las reservas expresadas, es posible afirmar que las nuevas reglas IFRS son aplicables en Chile de forma obligatoria sólo a sociedades y entidades bajo control de la SVS, siendo para el resto facultativo. Hasta la fecha existen 15 IFRS $^{74}$ y la gran mayoría han sido introducidas en Chile.

\subsubsection{Otras reglas especialísimas referidas a estados financieros.}

Existen otras reglas legales específicas, referidas a la contabilidad mercantil de otras entidades especiales, por ejemplo, respecto de la contabilidad de los bancos o en materias de insolvencia. Respecto de lo primero, se establece que es posible que los estados financieros bancarios no sean consolidados (art. 41 letra c LGBa), o que no son necesarias algunas medidas de publicidad vigentes para el resto de LSA (art. $49 \mathrm{n}^{\circ} 12 \mathrm{LGBa}$ ). El ente fiscalizador es la SBIF, quien posee además facultades para revisar libros, cuentas, archivos, documentos (art. $12 \mathrm{LGBa}$ ) y corregir la contabilidad (art. 15 inc. $2^{\circ}$ ), ha regulado los aspectos contables de los entes sometidos a su control por medio de la CIR-SBIF $n^{\circ}$ 3.410 .

En materia de insolvencia, la Superintendencia del ramo posee también entre sus atribuciones fiscalizadoras, la facultad de revisar libros, cuentas, archivos, documentos, contabilidad (art. $8 \mathrm{n}^{\circ} 2$ Ley 18.175 20.10.1982).

Es de destacar, que el sector público también posee sus propias reglas de presentación de estados financieros y rendición de cuentas, el denominado "Sistema de contabilidad general de la nación" que se rige por un conjunto de principios que constituyen la base sobre la cual se fundamenta la contabilidad en dicho sector. Estos principios deben ser aplicables a todas las entidades del Estado y a todos los hechos económicos, sin excepción.

deja de aplicar integramente la norma IFRS" disponible en http://www.americaeconomia.com/analisisopinion/chile-deja-de-aplicar-integramente-la-norma-ifrs [consultado por última vez el 15.12.2015]

${ }_{73}$ JARA, Luis, et al., "Adopción de IFRS en empresas chilenas del sector eléctrico que cotizan en bolsa", Revista internacional Legis, (2008-2009), p. 133. Y esto con la salvedad de lo dicho en la nota $\mathrm{n}^{\circ} 7$.

${ }^{74}$ IFRS: $\mathrm{n}^{\circ}$ 1. Adopción por primera vez de las Normas Internacionales de Información Financiera, $\mathrm{n}^{\circ} 2$. Pagos basados en acciones, $n^{\circ} 3$. Combinación de negocios, $n^{\circ} 4$. Contratos de seguro, $n^{\circ} 5$. Activos no corrientes mantenidos para la venta y operaciones discontinuadas, $\mathrm{n}^{\circ} 6$. Exploración y evaluación de recursos minerales, $\mathrm{n}^{\circ}$ 7. Instrumentos financieros: Información a revelar, $\mathrm{n}^{\circ}$ 8. Segmentos de operación. $\mathrm{n}^{\circ} 9$. Instrumentos financieros, $\mathrm{n}^{\circ} 10$. Estados financieros consolidados, $\mathrm{n}^{\circ} 11$. Acuerdos conjuntos, $\mathrm{n}^{\circ} 12$ Información a revelar sobre participaciones en otras entidades, $\mathrm{n}^{\circ} 13$. Valor razonable. A estas se agregaron el 01.01.2016 la $\mathrm{n}^{\circ} 14$. Cuentas regulatorias diferidas, y la $\mathrm{n}^{\circ} 15$ Ingresos de Actividades Ordinarias Procedentes de Contratos con Clientes (1u será válida desde 01.01.2018). 
Polít. crim. Vol. 11, № 21 (Julio 2016), Art. 10, pp. 264-306.

[http://www.politicacriminal.cl/Vol_11/n_21/Vol11N21A10.pdf]

Además deben observarse en forma uniforme, y estar en armonía con las disposiciones legales ${ }^{75}$.

Otras reglas sobre contabilidad y estados financieros son identificables en la ley del Banco Central, en ley de AFP y la ley de su respectiva superintendencia, otras leyes tributarias como la de timbre y estampillas, Ley de impuesto a la renta, y otras más, que en definitiva no añaden nada nuevo, sino que acotan el marco regulatorio antes expuesto al objeto de su regulación.

\subsection{Clases de estados financieros en la ley chilena.}

Sobre la base del panorama antes visto, es posible proponer una clasificación de los estados financieros regulados en la legislación chilena ${ }^{76}$. La summa divisio debe partir por distinguir entre estados financieros propias de las entidades pertenecientes al sector público y estados financieros regulados para negocios o relaciones del sector privado. Los primeros se identifican con los estados financieros de entidades estatales o semi-estatales en el contexto del Sistema de Contabilidad General de la Nación ${ }^{77}$, los segundos son confeccionados por los particulares, con fines mercantiles o fines tributarios según sea el caso.

Luego los estados financieros para fines mercantiles se distinguen por la forma en que son confeccionados, esto es, siguiendo la norma chilena contable PCGA, desarrolladas por el Colegio de contadores, o aquellas que deben confeccionarlos según los nuevos estándares internacionales IFRS.

A su vez, los estados financieros para efectos tributarios se distinguen entre complejos o simplificados, los primeros, involucran contabilidad completa y llevar la firma de un contador, y los segundos presentados en una mera planilla de situación patrimonial firmada por el propio contribuyente ${ }^{78}$.

Finalmente se pueden clasificar los estados financieros según su obligatoriedad. Así se distinguen los legalmente obligatorios, los contractuales y los voluntarios. Los primeros serían todos aquellos exigidos por ley (por ej. LSA), los segundos aquellos que nacerían del contrato y del deber de dar cuenta (por ej. la contabilidad mercantil en sociedades civiles o

\footnotetext{
${ }^{75}$ Estos principios son: Entidad Contable, Período Contable, Devengado, Realización, Bienes Económicos, Dualidad Económica, Moneda como unidad de medida, Entidad en marcha, Costo como base de valuación, Exposición, Objetividad, Equidad, Criterio Prudencial y Significación e Importancia Relativa. Ver Contraloría General de la República, Ver: "Fundamento Operacional del Sistema de Contabilidad General de la Nación”. Oficio Contraloría general de la República (en adelante CGR) nº 37.541/88.

${ }^{76}$ SCHÜPPEN, Systematik und Auslegung des Bilanzstrafrechts, cit. nota ${ }^{\circ} 2$, pp. 26-28, a quien en parte se sigue en la clasificación propuesta.

${ }^{77}$ No es el caso referirnos a este sistema, pero en líneas generales se aplica a entidades estatales y empresas públicas. Su entidad fiscalizadora es la Contraloría General de la Republica. Ver Oficio CGR N ${ }^{\circ}$ 60.820, (29.12.2005).

${ }^{78}$ Como se dijo en el apartado 2.1.3, el sistema tributario suele solaparse con el mercantil, no obstante, tanto en Derecho comparado como en Chile la ley los separa claramente tanto por los fines que persigue como por los sujetos obligados a cada uno. Sobre importancia de relaciones entre ambas contabilidades ver CIR-SII ${ }^{\circ}$ $08(07.02 .2000)$.
} 
VARELA, Luis. "Delitos contables mercantiles en el Derecho penal económico chileno: Sistematización de su marco regulatorio, elementos comunes de sus tipos penales y desafíos pendientes".

de personas), y los terceros aquellos que quedan entregados a la mera decisión del sujeto (por ej. uno que se presente por simple transparencia activa voluntaria, o en el proceso de obtención de un crédito).

\subsection{Principios de contabilidad presentes en el marco regulatorio de los estados financieros.}

Los principios que pueden ser identificados en la regulación chilena sobre estados financieros, son todos deducibles de distintas normas presentes en el marco legal, o de partes del contexto de regulación. El catalogo se puede reducir a lo menos a los siguientes principios:

- Principio de veracidad (arts. 10 inc. $2^{\circ}$ LMV, 4 letra g DL-SVS, 17 inc. $1^{\circ}$ CT). Conforme a este principio, los estados financieros deben coincidir con la realidad, y reflejar de forma objetiva e intersubjetivamente comprobable, el estado patrimonial de la empresa en cuestión ${ }^{79}$. Es contrario a este principio toda manipulación, falsedad, (di)simulación (make up) de la contabilidad.

- Principio de claridad (art. 74 inc. $2^{\circ}$ LSA). De acuerdo a este principio, el contenido concreto de cada uno de los asientos contables y la relación entre éstos debe ser entendible e inequívoco ${ }^{80}$. En lo sustancial y en lo formal, es contrario a este principio el hecho de no llevar contabilidad conforme a las reglas contables comúnmente aceptadas.

- Principio de suficiencia (arts. 10 inc. $2^{\circ}$ LMV, 4 letra g DL-SVS). La suficiencia está referida a la completitud de la información patrimonial expresada en las distintas partes de los estados financieros, esto significa, que tanto el pasivo como el activo de la empresa, tanto el corto como el mediano plazo, deben ser reflejados íntegramente, de modo tal que expresen el estado patrimonial total del respectivo periodo contable ${ }^{81}$. Presentar estados financieros incompletos, esto es, que no reflejen toda la actividad del ejercicio, contradice este principio.

- Principio de periodicidad y oportunidad (arts. 10 inc. $2^{\circ}$ LMV, 4 letra g DL-SVS). Ambos principios se abordan en conjunto porque dicen relación con aspectos referidos a los estados financieros en el tiempo. La periodicidad se refiere al hecho que los estados financieros y su proceso de confección no debe ser realizado temporalmente de forma discrecional, sino en lapsos prefijados y en principio iguales, siendo la regla general la anualidad. La oportunidad por su parte se refiere al momento temporal que se representa el concreto estado financiero, en el sentido que este deberá reflejar el presente próximo, en otras palabras, a final de un año contable, se deberá informar el pasado año y no otro ${ }^{82}$. Es una conducta contraria a estos principios, la omisión de confección de estados financieros y la falta de coincidencia temporal de los asientos contables con el periodo concreto que se informa.

\footnotetext{
${ }^{79}$ BAETGE, Jörg, et al., Bilanzen, 12. Aufl., Düsseldorf: IDW-Verl., 2012, p. 115.

${ }^{80}$ BAETGE, et al., Bilanzen, cit. nota ${ }^{\circ} 79$, pp. 118-119.

${ }^{81}$ BAETGE, et al., Bilanzen, cit. nota ${ }^{\circ} 79$, pp. 119-120.

${ }^{82}$ BAETGE, et al., Bilanzen, cit. nota $\mathrm{n}^{\circ} 79$, p. 120.
} 
Polít. crim. Vol. 11, № 21 (Julio 2016), Art. 10, pp. 264-306.

[http://www.politicacriminal.cl/Vol_11/n_21/Vol11N21A10.pdf]

- Principio de imparcialidad (arts. 74 inc. $2^{\circ}$, y 239 inc. final LMV). Conforme a este principio, la información financiera generada desde la empresa debe reflejar de forma objetiva, tanto los beneficios obtenidos como también las pérdidas sufridas durante el en un juicio o en sede extrajudicial, sirve como un "retrato" del estado patrimonial que hace fe de lo afirmado ${ }^{83}$.

\subsection{Función de los estados financieros en la ley chilena.}

La doctrina comparada distingue una serie de funciones que el marco regulatorio le asigna a los estados financieros, estos serían:

- Función de rendición de cuenta y facilitación del control. Conforme al art. 2080 del CC, el que administra una sociedad, tiene el deber de dar cuenta de su gestión ante los demás socios o accionistas (arts. 46 y 75 LSA en el caso del directorio), y hacerse responsables por ésta. En esta labor de rendición de cuentas son esenciales los estados financieros, pues los mismos posibilitan que la cuenta sea documentada y precisa ${ }^{84}$, lo que a su vez permite controles internos como externos del gobierno y administración corporativa.

- Función de conservación del patrimonio. Toda empresa requiere de un patrimonio para ejercer su giro, cuestión esencial en las SA (art. $332 \mathrm{~N}^{\circ} 4$ CCom, art. $4 \mathrm{~N}^{\circ} 5$ y 10 ss. LSA), en las que el capital social es elemento constitutivo ${ }^{85}$. En la SA el patrimonio se corresponde con las obligaciones de la empresa para con sus accionistas, esto es, la parte residual en los activos de la empresa, una vez deducido todos sus pasivos ${ }^{86}$. Por ello, los estados financieros juegan un rol capital en la tutela y vigilancia por parte de los accionistas de dicho capital, por lo cual, la función de conservación abarca asimismo la protección de los intereses de los acreedores de la SA y la posibilidad de pagar las deudas que se tengan con éstos.

- Función de repartición de utilidades. Los estados financieros posibilitan la comprobación de la existencia de utilidades (art. 78 LSA). En el caso que éstas existan, son la base para su repartición, y para la operatividad de las reglas sobre el particular.

- Función de información. Como se pudo ver, tanto en el DL-SVS como en las LSA y LMV existen un conjunto de deberes de entrega de información financiera para las SA (por ej. arts. 46 y 76 LSA). En el supuesto que la confianza es esencial para el libre mercado, esta función está orientada a permitir a los partícipes de aquel el ejercicio de su libertad de inversión sin que ella se encuentre determinada por maquinaciones que oculten la realidad patrimonial de las empresas.

${ }^{83}$ En principio la información contable hace fe en contra de quien la confecciona, cfr. HAGEDORN, Bilanzstrafrecht, cit. nota $\mathrm{n}^{\circ} 31$, p. 27.

${ }^{84}$ KANITZ, Bilanzkunde für Juristen, cit. nota ${ }^{\circ} 30$, p. 54.

${ }^{85}$ PUELMA, Alvaro, Sociedades, T. I, $3^{\mathrm{a}}$ ed., Santiago: Editorial Jurídica de Chile, 2001, pp. 67 y ss.

${ }^{86}$ TORRES SALAZAR, Gabriel, Estados Financieros, $4^{\mathrm{a}}$ ed., Santiago, Chile: Editorial Juridica Conosur, 2001, p. 8. Un marco conceptual oficial de las IFRS, disponible en http://www.ifrs.org/IFRSs/Pages/IFRS.aspx [consultado por última vez el 15.11.2015] 
VARELA, Luis. "Delitos contables mercantiles en el Derecho penal económico chileno: Sistematización de su marco regulatorio, elementos comunes de sus tipos penales y desafíos pendientes".

\subsection{Otros instrumentos en que se presenta situación patrimonial de la empresa.}

Finalmente se debe recalcar que, en la legislación chilena aparte de la presentación de estados financieros expresados en libros contables, es posible entregar esta clase de información en otros instrumentos no contables como: memorias, informes, prospectos de información al público, que como tales pueden constituirse en objetos materiales o medios comisivos para perpetrar delitos de Derecho penal de los estados financieros en sentido amplio.

\section{Elementos comunes de los delitos contables mercantiles presentes en la legislación chilena.}

\section{1. Áreas e inventario de los delitos contables mercantiles de la legislación chilena.}

Los delitos contables en sentido amplio son identificables en tres áreas (ver Gráfico 1.): en leyes mercantiles, en leyes tributarias y en la legislación sobre insolvencia.

Respecto de la primera, las reglas que establecen tipos penales se refieren a la regulación societaria de las SA, preferentemente las que participan en el mercado de valores y que se encuentran sometidas al control de la SVS, y a los bancos, los cuales, como vimos, deben necesariamente organizarse como SA (art. 27 LGBa). Luego, los delitos contables de carácter tributario se encuentran en el CT (art. $97 \mathrm{~N}^{\circ} 4,16$, y art. $\left.100 \mathrm{CT}\right),{ }^{87}$ mientras que el delito contable en situación de insolvencia ha vuelto a ser reintroducido al CP (art. 463 ter $\mathrm{N}^{\circ}$ 2) por la ley LRLEP (Ley 20.270 de 09.01.2014). Finalmente existen una serie de conductas que califican como delitos contables, que pueden ser subsumidas en los tipos penales de la estafa o de la falsedad de instrumento privado del CP.

\footnotetext{
${ }^{87}$ Aunque hay tipos sancionatorios tributarios contables en el art. $94^{\circ}$ 3, 4, 6, 7, 15 y asimismo en la Ley de Renta y en la Ley de Timbres y estampillas.
} 
Polít. crim. Vol. 11, № 21 (Julio 2016), Art. 10, pp. 264-306.

[http://www.politicacriminal.cl/Vol_11/n_21/Vol11N21A10.pdf]

Grafico 1. Áreas de los delitos contables en sentido amplio

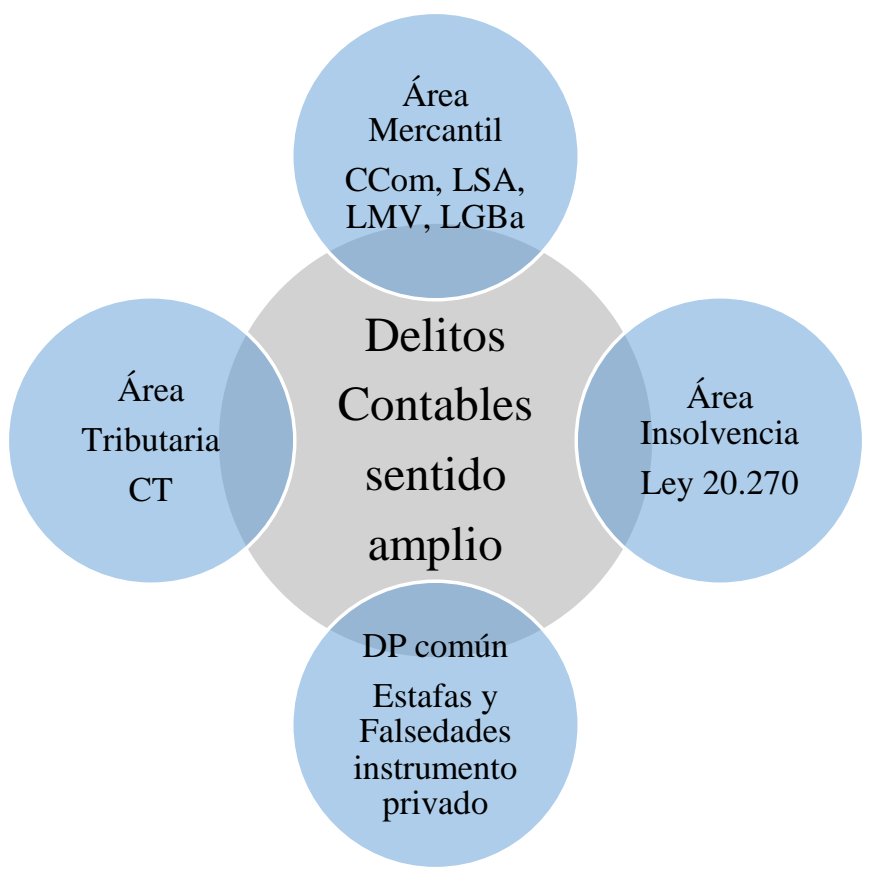

Luego, los delitos contables mercantiles en sentido estricto, presentes en la legislación chilena, excluyendo tipos sancionatorios, son los que a continuación se enumeran en la siguiente Tabla.

Tabla 1. Delitos contables mercantiles:

\begin{tabular}{|c|c|}
\hline En LSA & $\begin{array}{l}\text { Información o certificación falsa o fraudulenta de los estados financieros } \\
\text { realizadas por peritos, contadores o auditores externos que induzca a error a } \\
\text { accionistas o terceros que hayan contratado con la SA (art. 134 LSA). }\end{array}$ \\
\hline \multirow[t]{6}{*}{ En LMV } & $\begin{array}{l}\text { Entrega de antecedentes o certificaciones falsas sobre estados financieros. } \\
\text { información falsa o (di)simulada sobre el estado patrimonial real de la sociedad } \\
\text { (art 59. letra a). }\end{array}$ \\
\hline & $\begin{array}{l}\text { Dictamen falso de situación patrimonial realizadas por contadores y auditores (art. } \\
59 \text { letra d) }\end{array}$ \\
\hline & $\begin{array}{l}\text { Declaración falsa en antecedentes presentados ante SVS (estados financieros) o en } \\
\text { las noticias o propaganda divulgada al mercado realizadas por directores, } \\
\text { administradores y gerentes al emitir de valores de oferta pública (art. } 59 \text { letra f) }\end{array}$ \\
\hline & $\begin{array}{l}\text { Ocultamiento del estado patrimonial por entorpecimiento de la fiscalización de } \\
\text { estados financieros por parte de la SVS (art. } 60 \text { letra j). }\end{array}$ \\
\hline & $\begin{array}{l}\text { Delitos de entrega fraudulenta de información patrimonial, tanto la que se entrega } \\
\text { de forma tendenciosa a los partícipes del mercado de valores, cuando es realizada } \\
\text { por medio de estados financieros manipulados) (art. } 61 \mathrm{LMV} \text { ) como en su uso } \\
\text { indebido (art. } 60 \text { letra e). }\end{array}$ \\
\hline & $\begin{array}{l}\text { Obstrucción a la fiscalización de la SVS por eliminación, alteración, ocultación o } \\
\text { destrucción de registros contables (art. } 60 \text { letra j). }\end{array}$ \\
\hline En LGBa & $\begin{array}{l}\text { Ocultación, manipulación e inutilizado de los libros contables del banco y } \\
\text { antecedentes justificativos de los mismos (art. } 142 \mathrm{~N}^{\circ} \text { 6). [sólo aplicable a Bancos } \\
\text { en situación de liquidación forzosa] }\end{array}$ \\
\hline
\end{tabular}


VARELA, Luis. "Delitos contables mercantiles en el Derecho penal económico chileno: Sistematización de su marco regulatorio, elementos comunes de sus tipos penales y desafíos pendientes".

\begin{tabular}{|l|l|}
\hline & $\begin{array}{l}\text { Obstrucción a la fiscalización de la SBIF por medio de ocultación, destrucción, } \\
\text { alteración o desfiguración de antecedentes, de la contabilidad realizada por } \\
\text { accionistas fundadores, directores, gerentes, funcionarios, empleados o auditores } \\
\text { externos. } \\
\text { Existe además en el mismo artículo el delito de proporcionar, suscribir o presentar } \\
\text { esos elementos de juicio alterados o desfigurados. (art 158) }\end{array}$ \\
& $\begin{array}{l}\text { Omisión de contabilidad de operaciones relevantes que afecte patrimonio o } \\
\text { responsabilidad realizada por la empresa. Responde su gerente general o quien } \\
\text { haga sus veces, en una situación de responsabilidad penal por acto de tercero (art. } \\
\text { 159) }\end{array}$ \\
\hline $\begin{array}{l}\text { Obtención fraudulenta de créditos por medio de la entrega datos falsos acerca de } \\
\text { estados de situación o patrimonio, ocasionando perjuicios al Banco o institución } \\
\text { financiera. (art. 160) }\end{array}$ \\
\hline
\end{tabular}

Como se puede apreciar, estos delitos aparecen en cada uno de los momentos del proceso de la contabilidad jurídicamente regulada, esto es: en cuanto al deber de confección (omisión de contabilidad), durante su exhibición (ocultación, manipulación, dictamencertificación falsa), al momento de su control (dictamen falso de auditores, obstrucción a la fiscalización).

\subsection{Elementos comunes.}

\subsubsection{Naturaleza jurídica.}

Se discute en doctrina si esta familia de delitos sería una especie de estafa o una especie de falsedad, o si por el contario tiene contornos propios que lo definen independientemente de las figuras delictivas nombradas. Los autores que sostienen la primera opinión, se encuentran principalmente en la doctrina alemana ${ }^{88}$. Argumentan que estos delitos serían una especie de estafa (Betrug) con caracteres propios: como el hecho de que el círculo de destinatarios de la manipulación u ocultamiento sería indeterminado, que no se exigiría el inducir a un error a otro para realizar disposiciones patrimonialmente relevantes -con la finalidad de evitar dificultades probatorias-, y finalmente que tampoco sería exigible un perjuicio patrimonial $^{89}$.

Otra parte de la doctrina, sobre todo la española ${ }^{90}$, afirma que los delitos contables serían una especie de falsedad documental sobre instrumento privado, en tanto que el sujeto activo como el objeto material serían especiales. El primero, sería un particular obligado por ley a

${ }^{88}$ TIEDEMANN, Klaus, Wirtschaftsstrafrecht: Besonderer Teil mit wichtigen Rechtstexten, 3. Aufl., München: Vahlen, 2011, p. 277.

${ }^{89}$ Con citas de autores que siguen esta posición, ver DUTTGE, Gunnar "22. Abschnitt Betrug und Untreue", en: DIETER DÖLLING, Gunnar Duttge, Dieter Rössner (Eds.), Gesamtes Strafrecht StgB, StPO, Nebengesetze, Handkommentar, 3. Aufl., Baden-Baden: Nomos Komentar, 2013, pp. 1504-1205.

${ }^{90}$ FARALDO CABANA, El delito societario de falsedad en documentos sociales, cit. nota n ${ }^{\circ} 40$, pp. 14-33. 
Polít. crim. Vol. 11, No 21 (Julio 2016), Art. 10, pp. 264-306.

[http://www.politicacriminal.cl/Vol_11/n_21/Vol11N21A10.pdf]

declarar documentalmente la verdad, y esto, en documentos que también serían en principio $\operatorname{privados}^{91}$.

Probablemente ambas posturas se basan en la especial forma que la cultura jurídica concreta de su país de origen ha desarrollado los contornos dogmáticos entre; "falsum" (o falsis romano) y el "stellionatus", y en la evolución histórica presente en ambas tradiciones $^{92}$.

Finalmente una tercera posición, sostiene que esta clase de delitos tendría una naturaleza propia, que para ser definida, debe tomar como coordenadas el objeto jurídico tutelado, la función de los estados financieros y la publicidad de información empresarial "como mecanismo posibilitador" de la confianza necesaria para el funcionamiento de la economía de libre mercado y la protección de la transparencia mercantil como interés (colectivo) y estado digno de tutela penal ${ }^{93}$.

\subsubsection{Bien jurídico.}

Para ilustrar el problema del bien jurídico, se aplicará la distinción entre objeto jurídico genérico, específico y sub-específico ${ }^{94}$, y una orientación basada en los efectos de la infracción de las normas subyacentes a esta parcela y a los fines que las mismas persiguen, en otras palabras, los fines y funciones del sistema de reglas de conductas referidos a la confección, exhibición y auditoría de los Estados descritos en el apartado 2.3.

Antes que todo, se debe destacar que uno de los rasgos específicos que define al Derecho penal económico es la preponderancia de la perspectiva supraindividual al momento de abordar el problema del objeto jurídico, lo que se traduce en que su teoría del bien jurídico debe partir por tener presente que éste posee una naturaleza colectiva, lo cual tiene incidencia en aspectos como imputación y justificación, en los cuales las tradicionales consideraciones en clave individual serían insuficientes ${ }^{95}$.

${ }^{91}$ MUÑOZ CONDE, Francisco, Derecho penal parte especial, 16 ${ }^{\mathrm{a}}$ ed., Valencia: Tirant lo Blanch, 2007, pp. 522-524. FARALDO CABANA, El delito societario de falsedad en documentos sociales, cit. nota $\mathrm{n}^{\circ} 40, \mathrm{p}$. 15. En España el tipo de falsedad de instrumento privado no incluye la falsedad ideológica.

92 En detalle, la evolución histórica de ambos delitos, en ambas tradiciones, Cfr. ROJAS, Luis Emilio, "Historia dogmática de la falsedad documental", Revista de derecho (Valparaíso), (2012), pp. 547-582.

${ }^{93}$ KRAKOW, Georg, "Bilanzdelikte als Informationsdelikte", en: KEPPERT, Thomas (Ed.), Bilanzdelikte, Wien: Linde, 2009, p. 87. En Chile una posición parecida, a propósito de la discusión sobre el bien jurídico en la falsificación de instrumento privado, POLITOFF LIFSCHITZ, Sergio, et al., Lecciones de derecho penal chileno parte especial, $2^{\mathrm{a}}$ ed., Chile: Editorial Jurídica de Chile, 2012, p. 555. En la doctrina chilenas, sobre la fe pública en sentido subjetivo (como confianza entre las personas), y en sentido objetivo (como certeza seguridad) ver VARGAS, Tatiana, Falsificación de instrumento privado: un estudio práctico entre la falsificación y la estafa, Santiago: Legal Publishing, 2013, p. 110.

94 JIMÉNEZ DE ASÚA, Luis, Tratado de derecho penal, T. III, 5ª ed., Buenos Aires: Losada, 1950, pp. 93 y ss. Una distinción propuesta en la doctrina italiana por Rocco y Battaglini.

95 TIEDEMANN, Wirtschaftsstrafrecht AT, cit. 3, n.m. 45. WITTIG, Wirtschaftsstrafrecht, cit. 39, p. 11. En Chile sobre el carácter colectivo de los bienes jurídicos del Derecho penal económico, ver MAYER, Laura, "La estafa como delito económico", Revista de Derecho (Valparaíso), Vol. XLI (2013), pp. 190 y ss. Sobre la insuficiencia de la "clave individual" al momento de abordar esta clase de delitos, cfr. LAMPE, ErnstJoachim, "Systemunrecht und Unrechtssysteme", Zeitschrift für die gesamte Strafrechtwissenschaft (ZStW), Vol. 106 (1994), pp. 703 y ss. 
VARELA, Luis. "Delitos contables mercantiles en el Derecho penal económico chileno: Sistematización de su marco regulatorio, elementos comunes de sus tipos penales y desafíos pendientes".

En este sentido, la doctrina ha propuesto variadas respuestas a la pregunta sobre cuál sería el bien jurídico genérico, por ejemplo, existe un consenso con matices, en la doctrina alemana que lo tutelado por esta rama del Derecho penal estaría dado por la noción de "orden económico", sea como conjunto de los fines de las reglas económicas vigentes ${ }^{96}$, como sistema económico consagrado en la constitución ${ }^{97}$, o como sistema de aseguramiento y control de la organización económica ${ }^{98}$. En España, si bien el CPE contiene una rúbrica referida a delitos contra el "orden socioeconómico" (Titulo XIII Libro II CPE), el cual, en palabras de Martínez-Bujan, ha causado gran controversia entre la doctrina española ${ }^{99}$, ésta se ha decantado por entenderlo como sinónimo de la denominada "Constitución económica", es decir, el conjunto de preceptos y normas de carácter constitucional que determinan el modelo económico a seguir por el Estado ${ }^{100}$.

En Chile, Novoa Monreal, pionero en el tema, denuncia la falta de claridad sobre el asunto $^{101}$ y propone una visión más bien referida a la tutela penal en torno a las potestades reguladoras de la economía por parte del Estado, entendiendo que el Derecho penal económico tendría como objeto jurídico:

“(...) la protección y preservación de un orden publico económico, este mismo bien jurídico constituirá el objeto de protecci6n general de los tipos penales destinados a prevenir hechos que signifiquen formas concretas de lesión o de puesta en peligro de él, según libre elección del legislador respectivo", y agrega que: “(...) todo delito económico tendrá como bien jurídico protegido propio algún aspecto del orden publico económico concreto establecido en un país determinado."102

Los constitucionalistas también han tratado el tema desde la perspectiva del denominado "orden público económico constitucional". Fermandois, autor adelantado en Chile, en cuanto a actualizar la idea de orden público económico a los nuevos principios políticoideológicos-económicos presentes en la Constitución de 1980 (en adelante CPR), propone que este orden debe ser definido como:

“(...) el adecuado modo de relación de todos los diversos elementos de naturaleza económica presentes en la sociedad, que permita a todos los agentes económicos, en la mayor medida posible y en un marco subsidiario, el disfrute de sus garantías

\footnotetext{
${ }^{96}$ TIEDEMANN, Wirtschaftsstrafrecht $A T$, cit. nota $\mathrm{n}^{\circ} 3$, n.m. 46.

${ }^{97}$ BOTTKE, Wilfried, "Criminalidad económica y Derecho criminal económico en la República Federal de Alemania", Revista Penal n 4 (1999), p 22.

${ }^{98}$ WITTIG, Wirtschaftsstrafrecht, cit. nota ${ }^{\circ} 39$, p. 11.

99 MARTÍNEZ-BUJÁN PÉREZ, Carlos, Derecho penal económico y de la empresa: Parte general, $5^{\mathrm{a}}$ ed., Valencia: Tirant lo Blanch, 2016, p. 119.

100 MUÑOZ CONDE, Francisco, "Cuestiones dogmáticas básicas en los delitos económicos", Revista Derecho Penal (1998), p. 68.

${ }^{101}$ NOVOA MONREAL, Eduardo, "Reflexiones para la determinacion y delimitación del delito económico", Anuario de Derecho Penal y Ciencias Penales, T. XXXV (1982), p. 45.

${ }^{102}$ NOVOA MONREAL, "Reflexiones para la determinación", cit. nota ${ }^{\circ} 101$, p. 65.
} 
Polít. crim. Vol. 11, No 21 (Julio 2016), Art. 10, pp. 264-306.

[http://www.politicacriminal.cl/Vol_11/n_21/Vol11N21A10.pdf]

constitucionales de naturaleza económica de forma tal de contribuir al bien común y a la plena realización de la persona humana." (la cursiva es mía) ${ }^{103}$.

Teniendo presente lo anterior, todo delito económico (entre ellos los delitos contables mercantiles) ${ }^{104}$ exhibirían un bien jurídico genérico denominado "orden público económico", el que para efectos de este trabajo, entenderemos como: "el conjunto de condiciones que facilitan y sustentan el funcionamiento de la economía conforme a lo establecido en el Derecho vigente" ${ }^{\$ 105}$, por ejemplo en Alemania, un sistema economía de libre mercado con Estado social de bienestar, en Chile, libre mercado con Estado subsidiario, ambos consagrados en sus respectivas CPR y en un corpus de leyes y reglamentos regulatorios de la economía ${ }^{106}$. El sistema económico vigente en Chile, entiende que la iniciativa privada -bajo el régimen de libre competencia- es el motor de la economía, ${ }^{107}$ por ende el sistema de libre mercado supone libertad en el tráfico, y para que ésta sea posible, es esencial que los sujetos económicos actúen efectivamente en forma libre, esto es, en el tema que nos convoca, que no lo hagan determinados por maquinaciones fraudulentas respecto de la información patrimonial de una determinada empresa, sino que por el contrario, lo hagan en un contexto de veracidad y transparencia efectiva. ${ }^{108}$ De esta forma, la circulación de la información patrimonial de los actores que participan en la economía, y en el caso chileno, con mayor énfasis en el mercado de valores, es consustancial a la verdadera libertad del tráfico económico consagrado en la "Constitución económica chilena"109.

Sin embargo, la abstracción del bien jurídico genérico descrito, debe ser concretizada hacia la identificación de sub-grupos de delitos distinguibles por su bien jurídico inmediato, esto es, por la identificación del interés directamente tutelado en un sentido técnico ${ }^{110}$. Este bien jurídico específico, en cuanto a los delitos contables, es aún objeto de discusión. Es distinguible dos grandes posturas: para algunos, serían los deberes de rendición de cuentas, transparencia e información patrimonial, mientras que, para otros, sería la protección del patrimonio de los terceros que se encuentran en potencial relación jurídico-económica con

\footnotetext{
${ }^{103}$ FERMANDOIS, Arturo, "El orden público económico bajo la Constitución de 1980", Ius Publicum, n 4 (2000), p. 76. También FERMANDOIS, Arturo, Derecho Constitucional Económico: Garantías Económicas, Doctrina y Jurisprudencia, T. I, $2^{\text {a }}$ ed., Santiago: Ediciones Universidad Católica de Chile, 2006, pp. 20 y ss.

${ }^{104}$ En Alemania no existe duda que los delitos que estudiamos pertenecen al Derecho penal económico. Ver RANSIEK, 8. Teil Gesellschaftsrechtliche, cit. 96, p. 965 y ss. En Chile, ver MAYER, "La estafa como delito económico", cit. nota n 96, p. 190, quien se refiere a ellos como fraudes cometidos en el ámbito bursátil.

${ }^{105}$ CERVINI SÁNCHEZ, Raúl, ADRIASOLA, Gabriel, El derecho penal de la empresa desde una visión garantista: metología, criterios de imputación y tutela del patrimonio social, Montevideo: B de F, 2005, pp. 63-65. Sobre bien jurídico en el Derecho penal económico ver TIEDEMANN, Klaus, Tatbestandsfunktionen im Nebenstrafrecht : Untersuchungen zu einem rechtsstaatlichen Tatbestandsbegriff, entwickelt am Problem des Wirtschaftsstrafrechts, Tübingen: Mohr, 1969, pp. 113 y ss.

${ }^{106}$ Ver JARASS, Hans D. y PIEROTH, Bodo, Grundgesetz für die Bundesrepublik Deutschland: Kommentar, 13. Aufl., München: Beck, 2014, pp. 397 y ss.

${ }^{107}$ Cfr. FERRADA, Juan Carlos, "La Constitucion economica de 1980. Algunas reflexiones críticas", Revista de Derecho Valdivia, T. XI (2000), pp. 51-53.

${ }^{108}$ Ver supra 2.3. Principio de veracidad y principio de claridad.

109 Para lo cual es sumamente relevante la función de información de los Estados financieros, ver supra, apartado 2.4.

${ }^{110}$ MARTÍNEZ-BUJÁN PÉREZ, Derecho penal económico AT, cit. nota nº 99, pp. 140, 159 y ss.
} 
VARELA, Luis. "Delitos contables mercantiles en el Derecho penal económico chileno: Sistematización de su marco regulatorio, elementos comunes de sus tipos penales y desafíos pendientes".

la empresa en cuestión. La opinión mayoritaria se decanta por lo primero, y entiende que la confianza de las personas en la exactitud-veracidad e integridad de la información sobre la situación patrimonial de una sociedad -o de un consorcio- debe ser considerado el bien tutelado $^{111}$. Este bien jurídico se deduciría de los deberes especiales que pesan sobre ciertas empresas y sociedades de exhibir su información financiera, lo cual estaría orientado a generar esta clase de confianza ${ }^{112}$. La posición contraria, propone que el patrimonio o la propiedad de los acreedores, socios, o terceros en situación de una potencial relación económica con la empresa, sería el bien jurídico protegido, el cual se vería afectado, o a lo menos puesto en peligro, con información falsa o fraudulenta. Por lo cual evitar el perjuicio patrimonial de terceros daría el quid de la tutela penal ${ }^{113}$.

Una tercera postura, minoritaria, afirma que lo protegido es la seguridad en el tráfico económico, y, por ende, entiende estos ilícitos como contrarios a la transparencia de la información necesaria para la seguridad de dicho tráfico, es decir un delito de información funcional al intercambio que ocurre en el mercado ${ }^{114}$.

En los limitados márgenes del presente trabajo, no se tomará posición sobre cuál de las teorías anteriores sobre el bien jurídico específico de los delitos contables es la más adecuada para nuestra regulación, máxime aún, cuando no existen aún suficientes estudios dogmáticos respecto de gran parte de los delitos contables presentes en el Derecho chileno y de que además el tema es una discusión abierta en la doctrina comparada. Por lo pronto, nos limitaremos a afirmar, que un estudio profundo sobre los principios y fines que informan al Derecho contable y su concreta evolución en el respectivo ordenamiento jurídico, y no la búsqueda de estos exclusivamente en el CP dará luces sobre el asunto en un trabajo futuro.

Junto a las consideraciones antes expuestas, no se debe pasar por alto el hecho que cada tipo penal presente en la legislación chilena, recibe especial influencia de su "objeto jurídico sub-específico", esto es, el aspecto peculiar que el interés tutelado presenta concretamente en su contexto legal, por ejemplo, en el caso de los delitos contables mercantiles, los deberes de todo comerciante junto a la confianza de los partícipes en el

111 Lo que conecta con el principio de suficiencia en relación a función de rendición de cuentas. TIEDEMANN, Wirtschaftsstrafrecht BT, cit. nota ${ }^{\circ}$ 88, pp.270-271; SCHÜPPEN, Systematik und Auslegung des Bilanzstrafrechts, cit. nota $\mathrm{n}^{\circ}$ 2, p. 105; DANNECKER, "§§ 331 - 342e HGB", cit. nota $\mathrm{n}^{\circ} 22$ n.m. 3; WITTIG, Wirtschaftsstrafrecht, cit. nota ${ }^{\circ} 39$, p. 429, que parece ser también la opinión mayoritaria en la doctrina comparada europea, por ejemplo, en Italia, ver FOFFANI, "Delitos societarios", cit. nota $\mathrm{n}^{\circ} 4$, p. 105. En España ver FARALDO CABANA, El delito societario de falsedad en documentos sociales, cit. nota $\mathrm{n}^{\circ} 40$, p. 39. En la jurisprudencia comparada pueden ser citadas las sentencias sobre el caso Balsam AG, el caso Banesto en España y el caso Parmalat en Italia

${ }^{112}$ Lo que conecta con el principio de periodicidad y oportunidad en relación con función de mantención del patrimonio. Ver TIEDEMANN, Wirtschaftsstrafrecht BT, cit. nota ${ }^{\circ} 88$, p. 270. En España ver FARALDO CABANA, El delito societario de falsedad en documentos sociales, cit. nota n ${ }^{\circ} 40$, p. 39.

${ }^{113}$ Perspectiva respecto de la cual toma importancia la función de conservación del patrimonio y repartición de utilidades. Ver también HELLMAN, Uwe; BECKEMPER, Kharatina, Wirtschaftsstrafrecht, 4. Aufl., Stuttgart: W. Kohlhammer Verlag, 2013, n.m. 384.

${ }_{114}$ Respecto de la cual es importante el principio de veracidad en contacto con función de información. Ver KRAKOW, "Bilanzdelikte als Informationsdelikte", cit. nota n 93, pp. 81-82. 
Polít. crim. Vol. 11, № 21 (Julio 2016), Art. 10, pp. 264-306.

[http://www.politicacriminal.cl/Vol_11/n_21/Vol11N21A10.pdf]

mercado de valores y el crédito, en el caso de la insolvencia, la protección del patrimonio de los acreedores, expresado es sus créditos para con el insolvente, y en el caso de los delitos tributarios, la protección de los intereses y medios materiales de la administración a través de la determinación de una base imponible de los contribuyentes que no dé lugar a la evasión y al fraude en el pago de los tributos.

En fin, independiente de la postura concreta que se adopte sobre el bien jurídico, los autores mayoritariamente consideran que los delitos contables serían delitos de peligro abstracto ${ }^{115}$, sea contra la confianza de las personas, o contra el patrimonio, aunque un autor tan importante como Tiedemann sostiene una opinión contraria, pues considera "inconsecuente" a la doctrina dominante que alzaprima la confianza entre las personas como objeto de tutela y que no considera que la confianza sea "lesionada" con la información falseada. En su opinión una concepción en clave de peligro sería justificable si se considerase a la propiedad como bien jurídico protegido, cuestión que no hace la corriente mayoritaria según se señaló ${ }^{116}$.

\subsubsection{Objeto de protección y objeto material.}

El objeto de protección de esta clase de delito sería el interés de los partícipes en el tráfico jurídico en la veracidad de la información sobre el real estado financiero de una empresa (art. 4 letra d DL-SVS), esto es, los datos fácticos sobre su verdadera situación patrimonial en un determinado momento -generalmente anual-, expresada en asientos contables contenidos en registros permanentes (art. 73 LSA) o en informes financieros exigidos por la ley.

El objeto material por su parte es identificables con las formas concretas en que la información patrimonial es expresada en asientos contables, contenidos a su vez en libros de contabilidad, sean materiales o electrónicos. La ley y reglamentos distinguen los siguientes libros para efectos mercantiles:

- Balance general (arts. $25 \mathrm{n}^{\circ} 3$ CCom y 74 LSA), cuyo contenido es el resumen de los recursos económicos expresados en activos y pasivos puesto frente a frente bajo la técnica de partida doble ${ }^{117}$, el que a su vez es preparado sobre la base del libro mayor ${ }^{118}$ (art. $25 \mathrm{n}^{\circ}$ CCom).

\footnotetext{
115 SCHÜPPEN, Systematik und Auslegung des Bilanzstrafrechts, cit. nota $\mathrm{n}^{\circ} 2$, p. 174. DANNECKER, "§§ 331 - 342e HGB", cit. nota n $^{\circ} 22$, p. 56. Crítico con la creciente tendencia de introducir bienes jurídicos de peligro abstracto, GUZMÁN DALBORA, José Luis, Figuras y pensamientos del Derecho penal contemporanéo, Buenos Aires: B de F, 2014, pp. 24-25.

116 TIEDEMANN, Wirtschaftsstrafrecht BT, cit. nota $\mathrm{n}^{\circ} 88$, p. 271. Sobre delitos de peligro en la legislación chilena ver CABEZAS, Carlos, "Los delitos de conducción bajo la ingesta de alcohol o sustancias estupefacientes como delitos de peligro", Revista de Derecho (Valparaíso), XXXIV (2010), pp. $247-263$.

117 TORRES SALAZAR, Estados Financieros, cit. nota n ${ }^{\circ} 86$, p. 5.

118 TORRES SALAZAR, Estados Financieros, cit. nota ${ }^{\circ}$ 86, p. 9.
} 
VARELA, Luis. "Delitos contables mercantiles en el Derecho penal económico chileno: Sistematización de su marco regulatorio, elementos comunes de sus tipos penales y desafíos pendientes".

- Estado de cuentas de ganancias y pérdidas (art. 74 inc. $2^{\circ}$ LSA), también llamado estado de resultados, que da cuenta de los costos expirados y gastos incurridos (pérdidas) y los ingresos económicos (ganancias) y que reflejan la existencia o no de utilidades. ${ }^{119}$

- Inventario (art. 135 inc. $1^{\circ}$ Re-LSA), que es el registro detallado de todos los bienes, stocks y deudas de la empresa.

También son relevantes estados financieros no contemplados en la ley, pero recomendados por normas internacionales de contabilidad, y que cabrían dentro de la noción amplia de estados financieros contables (art. 4 letra d DL-SVS) ${ }^{120}$, como por ejemplo:

- Estado de flujo efectivo, también llamado, estado de flujo de caja, que muestra los ingresos y egresos de una empresa en cuanto a sus recursos líquidos en un periodo de tiempo determinado ${ }^{121}$.

- Estado de cambios en el patrimonio, que es un informe, sobre la variación del patrimonio de una empresa a partir de los saldos iniciales de ejercicio ${ }^{122}$.

Por último, serían también objetos materiales, ciertos informes financieros, los que, sin ser técnicamente estados financieros contables, la ley los contempla como medios para comunicar la situación patrimonial de la empresa ya expresada previamente en la contabilidad, por ejemplo:

- Memoria del directorio, esto es el breve informe que el órgano directivo de una SA entrega a la Junta de accionistas ${ }^{123}$.

- Prospectos para el público, que presentan una exposición o anuncio breve dirigido al público indiscriminadamente considerado sobre los aspectos financieros generales de la SA que participa en una transacción de valores ${ }^{124}$.

- Informes financieros especiales, los cuales pueden ser pedidos por los entes reguladores a la sociedad, a su directorio, a directores en particular, o al gerente general, para que

119 TORRES SALAZAR, Estados Financieros, cit. nota ${ }^{\circ}$ 86, p. 11

120 La SVS exigía que se indicase todos en el formulario FECU. Cfr. TORRES SALAZAR, Estados Financieros, cit. nota ${ }^{\circ} 86$, pp. 30 y ss.

121 TORRES SALAZAR, Estados Financieros, cit. nota ${ }^{\circ} 86$, p. 18. Introducido como estado financiero básico por la NIC 7 a contar de 1994, y en Chile a partir de 1996. En este sentido, y conforme a la CIR-SVS $\mathrm{n}^{\circ} 1.924$ las empresas que presenten sus estados financieros bajo modalidad IFRS deben agregar los siguientes informes contables: "Estado de Situación Financiera" (equivalente al antiguo Balance general conforme PCGA), "Estados de Resultados Integrales" (equivalente a Estado de Resultados), "Estado de Flujo de Efectivo" (mantiene nombre), "Estado de cambios en el patrimonio neto" (no considerado en el sistema PCGA) y las respectivas "Notas Explicativas" (se mantiene). La citada circular vino a modificar la CIR-SVS $\mathrm{n}^{\circ}$ 1501, que regulaba la presentación de estados financieros conforme a la PCGA.

${ }^{122}$ TORRES SALAZAR, Estados Financieros, cit. nota n ${ }^{\circ}$ 86, p. 26.

${ }^{123}$ PUELMA, Sociedades, cit. nota ${ }^{\circ}$ 48, p. 679.

${ }^{124}$ PUGA VIAL, La sociedad anónima, cit. nota $\mathrm{n}^{\circ}$ 45, p. 413. 
Polít. crim. Vol. 11, No 21 (Julio 2016), Art. 10, pp. 264-306.

[http://www.politicacriminal.cl/Vol_11/n_21/Vol11N21A10.pdf]

comuniquen aspectos concretos del estado financiero o transacciones de la entidad regulada $^{125}$.

\subsubsection{Esquema rector y conductas típicas.}

Si aplicamos la categoría de los esquemas rectores de Beling al grupo de hechos punibles que se han denominado delitos contables mercantiles ${ }^{126}$, y en consecuencia, agrupamos conforme a las imágenes representativas presentes en este grupo de delitos las abstracciones que los preceden lógicamente, es posible inducir el siguiente cuadro orientador de sus diferentes figuras.

Todo delito contable consiste en un ocultamiento o en un disimulo (make up) del real estado financiero de una empresa ${ }^{127}$. Se oculta el verdadero estado financiero de una empresa cuando se omite la confección de contabilidad, pero también, llevando contabilidad que no sigue las reglas contables aceptadas (ocultación por falla técnica) ${ }^{128}$. También, puede haber simple ocultación material cuando existiendo estado financiero correcto, éstos se esconden o inutilizan. Luego respecto del disimulo de los estados financieros, esto ocurrirá cuando hay manipulación de los asientos contables ${ }^{129}$, es decir (di)simulación de una situación patrimonial que no se tiene en la realidad, de modo tal que dichos asientos vienen a ser afirmaciones falsas o incorrectas, sea porque no se ajustan a la verdad (son falsos), sea porque son incompletos.

Luego es distinguible también un conjunto de figuras referidas al entorpecimiento del control de la corrección de los estados financiero por medio de auditoría o fiscalización. Que son conductas que buscan la ocultación o el disimulo en el contexto de su comprobación e inspección ${ }^{130}$. Acá encontramos la omisión de auditoría, la oposición a está o a la fiscalización, la manipulación de sus resultados - por ej. por medio del cohecho de los auditores-, o la simple ocultación de los objetos de fiscalización.

Finalmente aparece una figura nueva, conocida en Alemania como Bilanzeid (trad. lit. "contabilidad jurada", en el sentido de comprometerse a afirmar-certificar la verdad sobre la información de la situación patrimonial), cuyo origen es norteamericano, el cual involucra un compromiso legal de los directivos por la veracidad de la información que emana de la empresa, existiendo una especie de "perjurio" ante la falta de corrección de los estados financieros que emanan de ésta ${ }^{131}$.

\footnotetext{
${ }^{125}$ Por ejemplo, información solicitada por la SVS en virtud del citado art. 4 letra g del DL-SVS 3558

${ }^{126}$ BELING, Ernst von, "Die Lehre vom Tatbestand", en: HEGLER, August (Ed.), Reinhard von Frank zum 70. Geburtstag, 16. August 1930, Tübingen: Mohr, 1930, p. 5.

127 SCHÜPPEN, Systematik und Auslegung des Bilanzstrafrechts, cit. nota $\mathrm{n}^{\circ}$ 2, pp. 18-19, Cfr. también art. $42 \mathrm{n}^{\circ} 4$ LSA que prohíbe a directores ocultar informaciones esenciales a accionistas.

${ }^{128}$ SCHÜPPEN, Systematik und Auslegung des Bilanzstrafrechts, cit. nota $n^{\circ}$ 2, p. 22; DANNECKER, "\$ 28 Bilanzstrafrecht", cit. nota $\mathrm{n}^{\circ} 33$, p. 948.

${ }^{129}$ DANNECKER, "§ 28 Bilanzstrafrecht", cit. nota $\mathrm{n}^{\circ} 33$, p. 947.

${ }^{130}$ WITTIG, Wirtschaftsstrafrecht, cit. nota ${ }^{\circ} 39$, p. 437.

${ }^{131}$ FLEISCHER, Die Strafbarkeit der Abgabe eines unrichtigen Bilanzeids gemäß $\S 331 \mathrm{Nr}$. 3a HGB, cit. Kölner: Die Strafbarkeit, p. 108. En Chile en alguna medida, parecido al tipo penal del art. 26 inc. $3^{\circ}$ DLSVS.
} 
VARELA, Luis. "Delitos contables mercantiles en el Derecho penal económico chileno: Sistematización de su marco regulatorio, elementos comunes de sus tipos penales y desafíos pendientes".

Todas estas conductas son realizadas en el proceso empresarial interno de contabilidad por sujetos específicos que deben reunir ciertas características según se verá en el siguiente apartado.

\subsubsection{Sujetos activos.}

Existen tipos comunes y especiales. Los primeros no obstante la voz "el que" con el que se expresan, deben ser acotados a las personas que actúan en el contexto de regulación al que pertenece el tipo penal, en otras palabras, todo sujeto activo de estos delitos debe tener algún grado de participación relevante en el proceso contable de la empresa para ser considerados autor en sentido amplio ${ }^{132}$.

Los tipos especiales más recurrentes se refieren al órgano directivo de la empresa y al directivo de empresa propiamente tal -en Chile llamado por la ley, "ejecutivo principal"-_133 los contadores y los auditores ${ }^{134}$. Respecto de los dos primeros, existen reglas para los integrantes del órgano directivo de la SA, esto es, el directorio, en que se les prohíbe inducir a otros ejecutivos principales, dependientes, inspectores de cuentas o auditores externos y a las clasificadoras de riesgo, a rendir "cuentas irregulares", "presentar informaciones falsas" y "ocultar información" (art. $42 \mathrm{n}^{\circ} 3$ LSA), sumado al deber de garante que pesa sobre directorio en cuanto al hecho que la SA confeccione contabilidad (art. 45 LSA), y los deberes positivos de entregar información a accionistas y público (art. 46 LSA $)^{135}$. Todas las reglas mencionadas, son extensivas también al gerente general -en Chile representante legal- (arts. 49 LSA), y a los ejecutivos principales en general (art. 50 LSA), dentro del cual cabe la figura del representante de hecho ${ }^{136}$. Por lo mismo toma especial relevancia penal la fórmula de la cláusula de responsabilidad del art. 133 inc. $2^{\circ}$ LSA; "Por las personas jurídicas responderán además civil, administrativa y penalmente, sus administradores o representantes legales, a menos que constare su falta de participación o su oposición al hecho constitutivo de infracción", pues nada impediría que esta y su símil de los arts. 55 LMV, 159 LGBa, 99 CT (que reproducen el principio esbozado en el art. $58 \mathrm{CPrP}$ ) sean entendidas como normas de imputación que regularía expresamente la responsabilidad penal del directivo de estas personas jurídicas-empresas en clave de responsabilidad por conducta de un tercero. ${ }^{137}$

\footnotetext{
${ }^{132}$ RANSIEK, "8. Teil Gesellschaftsrechtliche", cit. nota n² 23, p. 970.

${ }^{133}$ PFEFFER, Francisco, "Nuevas normas sobre gobierno corporativo mayores responsabilidades para los directores de sociedades anónimas", Revista chilena de derecho, n 27 (2000), p. 495.

${ }^{134}$ La Ley 13.011 en su art. 24 inc. $1^{\circ}$ define la profesión de contador. Las empresas de auditoría externas están definidas en la LMV art. 239. En la práctica, la auditoría interna la realizan en Chile tanto contadores como los denominados ingenieros comerciales.

${ }^{135}$ Mejorar la calidad de la información es un elemento fundamental de la regulación de la reforma a la regulación de los gobiernos corporativos en Chile. Ver LEFORT, Fernando, "Hacia un mejor gobierno corporativo en Chile", Dirección de asuntos públicos PUC, 23 (2008), p. 8.

${ }^{136}$ PFEFFER, "Nuevas normas sobre gobierno corporativo", cit. nota n ${ }^{\circ} 133$, p. 496.

${ }^{137}$ En Chile urge debate dogmático sobre el particular. Importantes institutos del Derecho penal como la autoría mediata o la omisión impropia, han sido construidos sobre consideraciones e interpretaciones dogmáticas no reguladas expresamente en la ley.
} 
Polít. crim. Vol. 11, № 21 (Julio 2016), Art. 10, pp. 264-306.

[http://www.politicacriminal.cl/Vol_11/n_21/Vol11N21A10.pdf]

Como se adelantó, también hay tipos especiales para contadores y auditores, en la que el sujeto activo son dichos profesionales (art. 134 LSA), quienes deben perpetrar el delito en ejercicio de dicha profesión o función ${ }^{138}$.

Finalmente, se debe hacer presente, que respecto de ciertos tipos sancionatorios está contemplado en la ley chilena la posibilidad de responsabilidad administrativa de la empresa. Tal es el caso de las SA que infrinjan las disposiciones las leyes, reglamentos, estatutos y demás normas que las rijan, o en incumplimiento de las instrucciones y órdenes que les imparta la Superintendencia, (art. 27 DL-SVS).

\subsubsection{Sujeto pasivo.}

El marco legal permite identificar a quienes son los sujetos pasivos de estos delitos. En primer lugar, en las SA lo son los accionistas ${ }^{139}$, pero también en ciertos tipos sancionatorios los trabajadores (arts. 289 letra b y 292 CTr), como también terceros en relación de carácter económico presente o potencial con la empresa ${ }^{140}$. Por supuesto lo será también la sociedad indiscriminadamente considerada en todos los delitos que involucren información financiera para el público general y el Estado en los delitos que involucren oposición a la fiscalización por parte de los entes reguladores.

\subsubsection{Penas.}

Los distintos tipos penales de delitos contables presentes en la legislación chilena contemplan como penas principales: privativas de la libertad que tienen un marco legal que no sobrepasa el presidio menor en su grado máximo, multas penales especialmente graves en el caso de la LGBa (hasta 10.000 UTM) $^{141}$, y accesorias de inhabilidades para ejercer la profesión o la prohibiciones de ejercer puestos ejecutivos en la SA (art. 61 bis LMV).

\section{Conclusión}

De lo expuesto sobre los delitos contables mercantiles, es posible detenernos en tres puntos a título de conclusión: primero, una valoración sobre el nivel de avance de nuestra

\footnotetext{
${ }^{138}$ Sobre esta responsabilidad del perito, como experto que suple las limitaciones cognitivas de las personas a las cuales informa, ver a propósito del delito contra la administración de justicia de peritaje falso WILENMANN, Javier, "Sobre la estructura dogmática de los delitos de falsedad en el proceso", Ius et Praxis, $\mathrm{n}^{\mathrm{o}} 2$ (2014), pp. 1012-103. Una definición legal de contador y sobre su función en el art. 2 letra b y c respectivamente del Reglamento de la ley 13.011, DS $\mathrm{n}^{\circ} 15.141$ (11.12.1958).

${ }^{139}$ Un marco legal del accionista en el Titulo III LSA. Para una definición doctrinal ver PUGA VIAL, La sociedad anónima, cit. nota $\mathrm{n}^{\circ} 45$, p. 144, quien citando a Jean Guyenot agrega: "lo que vincula al accionista a la sociedad no es el contrato de sociedad ni la calidad de socio - que no tiene en el sentido habitual del término-, sino la tenencia de un título negociable: la acción".

${ }^{140}$ En Derecho comparado igual panorama. En Alemania, ver SCHÜPPEN, Systematik und Auslegung des Bilanzstrafrechts, cit. nota ${ }^{\circ}$ 2, pp. 101-106. En España, solo respecto del tipo básico del art. 290 (el agravado requiere perjuicio patrimonial de los socios). Cfr. MUÑOZ CONDE, Derecho penal parte especial, cit. nota ${ }^{\circ} 91$, pp. 522-524.

${ }^{141}$ Como sanciones administrativas el art. 27 del DL-SVS contemplan, multas administrativas (hasta un monto global por sociedad equivalente a $15.000 \mathrm{UF}$ ), clausura, revocación de la existencia de la sociedad, y censura.
} 
VARELA, Luis. "Delitos contables mercantiles en el Derecho penal económico chileno: Sistematización de su marco regulatorio, elementos comunes de sus tipos penales y desafíos pendientes".

legislación en comparación con la tendencia internacional, segundo, los desafíos científicos para la doctrina, y tercero, los desafíos políticos criminales aún existentes para el legislador.

1. En cuanto a lo primero. Chile continúa perfeccionando su derecho societario a la luz de las recomendaciones de la OCDE, la principal de ellas, la introducción de nuevos estándares contables IFRS por medio de normativa dictada por la SVS ${ }^{142}$. Junto a esto, la recepción de la doctrina de los Corporative Governance avanza hacia su plena implementación, haciendo cada vez más rigurosas las reglas de responsabilidad de los directivos de la sociedad, lo que ha posibilitado un desarrollo importante de esta disciplina ${ }^{143}$. No obstante esta halagüeño juicio, nuestro Derecho requiere mayor desarrollo en los puntos que veremos en el punto tres.

2. En lo referente a los desafíos científicos. El principal es el de sistematización. No existen en el medio chileno obras específicas que aborden esta importante parcela, y las que le dedican algunos párrafos, lo hacen de forma marginal, desde el Derecho penal de la insolvencia, o el Derecho penal tributario. Esta despreocupación puede tener como origen:

“(...) la imagen a primera vista de un complejo normativo encerrado por el legislador en los márgenes del sistema penal a modo de un mero apéndice sancionador de la disciplina privada, agobiado por una deficiente técnica legislativa que llega a hacer fatigosa -cuando no ininteligible- la comprensión del contenido preceptivo de las incriminaciones". ${ }^{144}$

3. Finalmente, en el ámbito político-criminal, el legislador chileno tiene aún una serie de desafíos pendientes. Por lo pronto, el principal, ampliar el radio de alcance de los delitos contables mercantiles a otras sociedades relevantes para el tráfico económico nacional, tales como las SRL que califiquen como "gran empresa", cuestión de suma importancia en un país minero como Chile, en el que una parte importante de las empresas de la gran minería que operan en el norte del país están organizadas según este modelo de sociedad de personas $^{145}$. Esta laguna de regulación, introduce sin duda, la posibilidad de manipulaciones contables que pueden ser sensibles para el orden público económico nacional en su totalidad, si éstos llegasen a afectar de forma generalizada a esta actividad clave para la economía interna. Junto a lo anterior, se presenta también como desafío, la utilización de los delitos contables como herramienta contra la corrupción en el ámbito privado ${ }^{146}$ y otros delitos en los que es detectable presencia de asientos contables "sucios"147.

142 El conjunto de NCG, circulares y oficios de la SVS están disponibles en http://www.svs.cl/portal/principal/605/w3-propertyvalue-18641.html [consultado por última vez 15.12.2015].

${ }_{143}$ PFEFFER, "Nuevas normas sobre gobierno corporativo", cit. 134, pp. 485-487.

${ }^{144}$ La cita textual es de Foffani. El severo juicio sobre la realidad de esta parcela en el contexto italiano, es válido para la realidad chilena. Ver FOFFANI, "Delitos societarios", cit. nota n 4, p. 58.

${ }^{145}$ Por ejemplo, la más grande de todas, Escondida Ltda. lo es. El alcance debería en principio ampliarse no a toda SRL (muchas son meras PYME), pero si a aquellas que poseen un gran capital y son actores relevantes del mercado.

${ }^{146}$ DANNECKER, "Die Bekämpfung der Korruption in Deutschland”, cit. nota n 4, p. 163.

${ }^{147} \mathrm{El}$ Informe del Consejo asesor presidencial contra los conflictos de interés, el tráfico de influencias y la corrupción (2015), confeccionado por la denominada "Comisión Engel", lo propone como un tema esencial, 
Polít. crim. Vol. 11, No 21 (Julio 2016), Art. 10, pp. 264-306.

[http://www.politicacriminal.cl/Vol_11/n_21/Vol11N21A10.pdf]

Pero lo que sin lugar a dudas es el mayor desafío legislativo en esta materia, es la introducción a la ley chilena un tipo penal de aplicación general para todo delito contable mercantil, que venga llenar el vacío penal cerrado ya en 1985 en Alemania por el $\$ 331$ HGB o en España en 1995 por el art. 290 CPE. Esto puede ser realizado, o introduciendo el nuevo tipo penal en el CCom aplicable a toda sociedad de capitales y las SLR con capital societario relevante, o en el CP según el modelo de los delitos societarios. Lo segundo, ha sido discutido en el último proyecto de reforma total del CP de $2014^{148}$. En dicho proyecto, se formuló una propuesta que debe ser calificada como un significativo avance, pues no sólo se limitó a plantear la codificación de los delitos contables de las distintas áreas del Derecho penal (insolvencia, tributaria, mercantil) ${ }^{149}$, sino que en lo que se refiere al ámbito mercantil propone un interesante art. 365 ( $\$ 4$ Titulo VIII) que establece un genuino delito contable mercantil denominado "Registro indebido de información social" "150, cuya estructura se construyó sobre la base de la omisión de registrar información patrimonial, o en el caso de hacerlo, incurrir en falsedades, alcanzando su ámbito de aplicación a toda persona jurídica comercial o empresa de auditoría externa. Junto a ello, se codifica en el mismo título, pero en el $\S 5$ los delitos contra el orden del mercado de valores, en el cual también se sistematizan y modernizan los tipos penales contables de las SA que participan del mercado bursátil (art 368 PCP 2014) y la obstrucción a la fiscalización por parte de los reguladores (art. 374 PCP 2014).

Al momento de escribir estas líneas, una nueva comisión de penalistas ha redactado un nuevo ACP 2015, el cual aún no se ha hecho oficialmente público y que se encuentra actualmente en revisión por parte del Ministerio de Justicia ${ }^{151}$. Éste sin duda aportará con

ver apartado IV letra c. El informe disponible en http://consejoanticorrupcion.cl/ [consultado por última vez 15.12.2015].

${ }^{148}$ El ACP 2005 no fue innovador en la materia. Propuso en su $§ 10$ Titulo XIII Libro Segundo un epígrafe titulado "Delitos societarios y contra el mercado de valores" que se limitó a codificar las normas vigentes dispersas en leyes especiales. El ACP 2005 es consultable en http://www.politicacriminal.cl/n_01/pdf_01/d__1.pdf Los materiales de estudios que tuvo a la vista el Foro Penal, no se refieren al tema de delitos contables ni al tema delitos societarios, cfr. http://www.politicacriminal.cl/n_01/pdf_01/d_3.pdf [ambos links consultados por última vez 15.12.2015].

${ }^{149}$ En efecto, el PCP 2014 recoge cada uno de los delitos contables: respecto de la insolvencia (art. 344), delitos contables mercantiles comunes (art. 365), mercantiles referidos al mercado de valores (arts. $368 \mathrm{y}$ 375), y tributarios (arts. 387 y 389). Además, se contemplan reglas comunes en el art. 383 que contempla una serie de pena de inhabilidades para los responsables. El PCP es consultable en Boletín 9274-07 del Senado, disponible en, http://www.senado.cl/appsenado/templates/tramitacion/index.php\# [consultado por última vez 15.12.2015].

${ }^{150}$ El tipo penal es el siguiente: Art. 365. Registro indebido de información social. El director, gerente, administrador, ejecutivo principal, contador, perito, auditor externo o inspector de una persona jurídica comercial, o empresa de auditoría externa en su caso, que en la memoria, balances u otros documentos de su competencia que se encuentren destinados a los socios, accionistas, a terceros o a la autoridad, exigidos por ley, reglamento o instrucciones de la autoridad, y que deban reflejar la situación económica o financiera de la sociedad, omitiere registrar información relativa a aspectos relevantes de la situación financiera de la entidad, o registrare información falsa o incompleta, será sancionado con la pena de multa, reclusión o prisión de 1 a 3 años, salvo que la conducta constituya otro delito sancionado con mayor pena.

${ }^{151}$ Cfr. en la página web del Ministerio de Justicia: "Ministra Javiera Blanco recibió el anteproyecto de nuevo Código Penal que será ingresado al parlamento este segundo semestre“ (02.07.2015) disponible en http://www.minjusticia.gob.cl/ministra-javiera-blanco-recibio-el-anteproyecto-de-nuevo-codigo-penal-quesera-ingresado-al-parlamento-este-segundo-semestre/ [consultado por última vez el 15.11.2010]. 
VARELA, Luis. "Delitos contables mercantiles en el Derecho penal económico chileno: Sistematización de su marco regulatorio, elementos comunes de sus tipos penales y desafíos pendientes".

propuestas a este importante tema, y en el caso que no lo haga, el Ministerio de Justicia debería agregarlo en su revisión, pues como se partió afirmando en la introducción, si algo ha quedado demostrado en los últimos casos de delitos económicos que han remecido a la opinión pública, es que la gran mayoría poseen elementos de delitos contables. 
Polít. crim. Vol. 11, № 21 (Julio 2016), Art. 10, pp. 264-306.

[http://www.politicacriminal.cl/Vol_11/n_21/Vol11N21A10.pdf]

\section{BIBLIOGRAFÍA}

ALCALDE, Enrique, La responsabilidad de los directores de sociedades anónimas; reponsabilidad civil y penal adminsitrativa, Santiago: Ediciones UC, 2013.

BAETGE, Jörg; KIRSCH, Hans-Jürgen; THIELE, Stefan, Bilanzen, 12. Aufl., Düsseldorf: IDW-Verl., 2012.

BELING, Ernst von, "Die Lehre vom Tatbestand", en: HEGLER, August (Ed.), Reinhard von Frank zum 70. Geburtstag, 16. August 1930, Tübingen: Mohr, 1930, pp. 1-23.

BERNET, Manuel, "El gobierno de las sociedades abiertas", Revista de Derecho, 16 (2004), pp. 33-57.

BOTTKE, Wilfried, "Criminalidad económica y Derecho criminal económico en la República Federal de Alemania”, Revista Penal, N4 (1999), pp. 21-29.

BRAVO HERRERA, Fernando, Análisis de estados financieros. Textos y casos, Santiago: Editorial Jurídica de Chile, 2011.

BRICKEY, Kathleen, “A la estela de Enron: Ejecutivos de corporación en juicio”, Anuario de Derecho penal económico y de la empresa, $\mathrm{N}^{\circ} 2$ (2012), pp. 143-161.

CABEZAS, Carlos, "Los delitos de conducción bajo la ingesta de alcohol o sustancias estupefacientes como delitos de peligro", Revista de Derecho PUCV, XXXIV (2010), pp. 227-280.

CERVINI SÁNCHEZ, Raúl; ADRIASOLA, Gabriel, El derecho penal de la empresa desde una visión garantista: metología, criterios de imputación y tutela del patrimonio social, Montevideo: B de F, 2005.

CIPOLLA, Carlo M., Geld-Abenteuer: Extravagante Geschichten aus dem europäischen Wirtschaftsleben, Berlin: Wagenbach, 1995.

CURY, Enrique, Derecho Penal Parte General, 9a ed., Santiago: Ediciones Universidad Católica de Chile, 2010.

DANNECKER, Gerhard, "§ 28 Bilanzstrafrecht", en: ROTSCH, Thomas (Ed.), Criminal Compliance, Baden-Baden: Nomos, 2015, pp. 933-971.

"§§ 331 - 342e", VII-2, en: STAUB, Hermann (Ed.), Staub-HGB, VII-2, 5. Aufl., Berlin: De Gruyter, 2012, pp. 481.

"Bilanzdelikte im internationalen Kontext", en: KEPPERT, Thomas (Ed.), Bilanzdelikte, Wien: Linde, 2009, pp. 97-130.

"Die Bekämpfung der Korruption in Deutschland durch das Straf- und Steuerrecht", en: DANNECKER, Gerhard (Ed.), Handbuch Korruption, Wien: Linde, 2012, pp. 159-210.

, Evolución del derecho penal y sancionador comunitario europeo, Madrid: Marcial Pons, 2001.

DANNECKER, Gerhard; BIERMANN, Jörg, "K. Steuer- und Bilanzstrafrecht", en: BLUMERS, Wolfgang; FRICK, Jörg; MÜLLER, Lutz (Eds.), Betriebsprüfungshandbuch, München: C.H. Beck, 2008, pp. K 1-229.

DUTTGE, Gunnar, "22. Abschnitt Betrug und Untreue", en: DIETER DÖLLING, Gunnar; DUTTGE, Dieter Rössner (Eds.), Gesamtes Strafrecht StgB, StPO, Nebengesetze, Handkommentar, 3. Aufl., Baden-Baden, Nomos Komentar, 2013, pp. 1464-1591.

EMMRICH, Markus, Ansätze und Perspektiven einer Reform der externen Rechnungslegung in Deutschladn, Aachen: Schaker, 1999. 
VARELA, Luis. "Delitos contables mercantiles en el Derecho penal económico chileno: Sistematización de su marco regulatorio, elementos comunes de sus tipos penales y desafíos pendientes".

FARALDO CABANA, Patricia, El delito societario de falsedad en documentos sociales, Valencia: Tirant lo Blanch, 2003.

FARALDO CABANA, Patricia; MARTÍNEZ-BUJÁN PÉREZ, Carlos, Los delitos societarios presupuestos de su criminalización en España, Memoria de Tesis doctoral, La Coruña: Universidad de la Coruña, 1995.

FARALDO CABANA, Patricia; VALEIJE, Inmaculada (Eds.), Actas I Congreso hispanoitaliano de derecho penal económico, La Coruña: Publicaciones de la Universidad de la Coruña, 1998, pp. 57-78.

FERMANDOIS, Arturo, Derecho Constitucional Económico: Garantías Económicas, Doctrina y Jurisprudencia, Tomo I, $2^{\mathrm{a}}$ ed., Santiago: Ediciones Universidad Católica de Chile, 2006.

"El orden público económico bajo la Constitución de 1980", Ius Publicum, N ${ }^{\circ}$ 4 (2000), pp. 63-78.

FERRADA, Juan Carlos, "La Constitucion economica de 1980. Algunas reflexiones críticas", Revista de Derecho Valdivia, XI (2000), pp. 47-53.

FLEISCHER, Ulrich, Die Strafbarkeit der Abgabe eines unrichtigen Bilanzeids gemäß $\S$ 331 Nr. 3a HGB, Berlin: Duncker \& Humblot, 2014.

FOFFANI, Luigi, "Delitos societarios", traducción de BRANDARIZ, José y PUENTE, Luz, en: FOFFANI, Luigi, "Delitos concursales y societarios", en: TIEDEMANN, Klaus; NIETO MARTÍN, Adan (Eds.), Eurodelitos: el derecho penal económico en la Unión Europea, Cuenca: Ediciones de la Universidad de Castilla-La Mancha, 2005, pp. 99-107.

FRENTROP, Paul, A History of Corporate Governance 1602-2002, Amsterdam: Deminor, 2003.

GOETZMANN, William, "Fibonacci and the Financial Revolution", NBER Working Paper, $\mathrm{n}^{\circ} 10352$ (2004), pp. 1-42.

GRATOPP, Jutta, Bilanzdelikte nach § 331 Nr. 1, Nr. la HGB, Münster: Lit-Verl., 2009.

GUZMÁN DALBORA, José Luis, Figuras y pensamientos del Derecho penal contemporanéo, Buenos Aires: B de F, 2014.

HAGEDORN, Niklas, Bilanzstrafrecht im Lichte bilanzrechtlicher Reformen, Berlin: Berliner Wiss.-Verl., 2009.

HELLMAN, Uwe; BECKEMPER, Kharatina, Wirtschaftsstrafrecht, 4. Aufl., Stuttgart W. Kohlhammer Verlag, 2013.

HERNÁNDEZ, Esteban, "Benedetto Cotrugli, precursor de Paciolli en la exposición de la partida doble", Cuadernos de Estudios Empresariales (Madrid), n 2 (1992), pp. 8799.

HOHL, Patrick, Private Standardsetzung im Gesellschafts- und Bilanzrecht: verfassungsrechtliche Grenzen kooperativer Standardsetzung im europäischen Mehrebenensystem an den Beispielen des Deutschen Corporate Governance Kodexes und der International Financial Reporting Standards, Berlin: Duncker \& Humblot, 2007.

JARA, Luis; CONTRERAS, Harold, "Adopción de IFRS en empresas chilenas. Énfasis en los efectos cuantitativos sobre la información financiera", Capic Review, (2010), pp. 13-24. 
Polít. crim. Vol. 11, No 21 (Julio 2016), Art. 10, pp. 264-306.

[http://www.politicacriminal.cl/Vol_11/n_21/Vol11N21A10.pdf]

JARA, Luis; CONTRERAS, Harold; CASTRO, Boris, "Adopción de IFRS en empresas chilenas del sector eléctrico que cotizan en bolsa", Revista internacional Legis, (2008-2009), pp. 130-163.

JARASS, Hans D.; PIEROTH, Bodo, Grundgesetz für die Bundesrepublik Deutschland : Kommentar, 13. Aufl., München: Beck, 2014.

JIMÉNEZ DE ASÚA, Luis, Tratado de derecho penal, III, 5a ed., Buenos Aires: Losada, 1950.

KANITZ, Friedrich von, Bilanzkunde für Juristen, 2. vollst. überarb. Aufl., München: Beck, 2010.

KRAKOW, Georg, "Bilanzdelikte als Informationsdelikte", en: KEPPERT, Thomas (Ed.), Bilanzdelikte, Wien: Linde, 2009, pp. 82-95.

KREKLAU, Jan, Das US-amerikanische Bilanzstrafrecht - Vorbild für das deutsche Bilanzstrafrecht?, Bayreuth: Verl. P.C.O., 2008.

LAMPE, Ernst-Joachim, "Systemunrecht und Unrechtssysteme", Zeitschrift für die gesamte Strafrechtwissenschaft, Vol. 106 (1994), pp. 683-745.

LEFORT, Fernando, "Hacia un mejor gobierno corporativo en Chile", Dirección de asuntos públicos PUC, $\mathrm{N}^{\circ} 23$ (2008), pp. 1-11.

MARTÍNEZ-BUJÁN PÉREZ, Carlos, Derecho penal económico y de la empresa: Parte general, $5^{\mathrm{a}}$ ed., Valencia: Tirant lo Blanch, 2016.

MAYER, Laura, "La estafa como delito económico", Revista de Derecho PUCV, XLI (2013), pp. 183-209.

MEKAT, Martin, Der Grundsatz der Wesentlichkeit in Rechnungslegung und Abschlussprüfung, Baden-Baden: Nomos, 2009.

MEYER, Claus, Bilanzierung nach Handels- und Steuerrecht : unter Einschluss der Konzernrechnungslegung und der internationalen Rechnungslegung ; Kontrollfragen, Aufgaben und Lösungen, Lernprogramm ; [Online-Training inklusive!], 26., vollst. überarb. Aufl., Herne: NWB, 2015.

MOCK, Sebastian, Finanzverfassung der Kapitalgesellschaften und internationale Rechnungslegung, Köln; München: Heymann, 2008.

MUÑOZ CONDE, Francisco, "Cuestiones dogmáticas básicas en los delitos económicos", Revista Derecho Penal, (1998), pp. 67-76.

, Derecho penal parte especial, 16 ${ }^{\mathrm{a}}$ ed., Valencia: Tirant lo Blanch, 2007.

NOVOA MONREAL, Eduardo, "Reflexiones para la determinacion y delimitación del delito económico", Anuario de Derecho Penal y Ciencias Penales, TOMO XXXV (1982), pp. 43-75.

OCAMPO, José Gabriel; BRAHM GARCÍA, Enrique (Eds.), José Gabriel Ocampo y la codificación comercial chilena los primeros borradores del proyecto de código de comercio : tomo I, Santiago: Editorial Universidad de Los Andes, 2000.

PALMA, Gabriel, Derecho Comercial, T. I, Santiago: Talleres Gráficos Artulfo, 1935.

PELLENS, Bernhard, Internationale Rechnungslegung : IFRS 1 bis 8, IAS 1 bis 41, IFRICInterpretationen, Standardentwürfe; mit Beispielen, Aufgaben und Fallstudie, Stuttgart: Schäffer-Poeschel, 2008.

PFEFFER, Francisco, "Nuevas normas sobre gobierno corporativo mayores responsabilidades para los directores de sociedades anónimas", Revista chilena de derecho, $\mathrm{N}^{\circ} 27$ (2000), pp. 485-499. 
VARELA, Luis. "Delitos contables mercantiles en el Derecho penal económico chileno: Sistematización de su marco regulatorio, elementos comunes de sus tipos penales y desafíos pendientes".

PIZARRO, Verónica, "Reconocimiento de intangibles y valoración de mercado; Influencia de las IFRS en Chile", Revista Contabilidad y sistemas, Vol II (2007), pp. 3-11.

POLITOFF LIFSCHITZ, Sergio; MATUS ACUÑA, Jean Pierre; RAMÍREZ GUZMÁN, María Cecilia, Lecciones de derecho penal chileno parte especial, $2^{\mathrm{a}}$ ed., Santiago: Editorial Jurídica de Chile, 2012.

POLITOFF, Sergio; MATUS, Jean Pierre, "§1. De las penas en general; Artículos 18 a 49", en: POLITOFF, Sergio; ORTIZ, Luis (Eds.), Texto y comentario del Código penal chileno, Santiago: Editorial jurídica de Chile, 2002, pp. 263-322.

PUELMA, Alvaro, Sociedades, II, $3^{\mathrm{a}}$ ed., Santiago: Editorial Jurídica de Chile, 2001. , Sociedades, I, $3^{\mathrm{a}}$ ed., Santiago: Editorial Jurídica de Chile, 2001.

PUGA VIAL, Juan Esteban, Derecho concursal delitos de la quiebra, $2^{\mathrm{a}}$ ed., Santiago: Editorial Jurídica de Chile, 2002.

, La sociedad anónima y otras sociedades por acciones en el derecho chileno y comparado, Santiago: Editorial Jurídica de Chile, 2011.

RANSIEK, Andreas, "8. Teil Gesellschaftsrechtliche Bilanz-, Prüfer und Falschangaben", en: ACHENBACH, Hans; RANSIEK, Andreas; RÖNNAU, Thomas; BECKEMPER, Katharina (Eds.), Handbuch Wirtschaftsstrafrecht, 4. Aufl., Heidelberg: Müller, 2015, pp. 963-1050.

REINSTEIN, Andre; ROSENDE, Francisco, "Capitulo 9: La transformación financiera en Chile", en: LARRAÍN, Felipe; VERGARE, Rodrigo (Eds.), La transformación económica en Chile, $2^{\mathrm{a}}$ ed., Santiago: Publicaciones Centro de Estudio Públicos, 2001, pp. 342-391.

ROJAS, Luis Emilio, "Historia dogmática de la falsedad documental", Revista de derecho (Valparaíso), (2012), pp. 545-583.

RÜCKERT, Sabrina, Die Einführung der obligatorischen Buchführung: eine rechtshistorische Untersuchung über die Anfänge und die Entwicklung des Bilanzrechts in Frankreich und Deutschland, Berlin; Münster: Lit, 2009.

SANDOVAL, Ricardo, Derecho Comercial, Vol. I, T. II, $7^{\mathrm{a}}$ Ed., Santiago: Editorial Jurídica de Chile, 2009.

SANGSTER, Alan; SCATAGLINIBELGUITAR, Giovanna, "Luca Pacioli: The Father of Accounting", Accounting Education: an international journal Education, Vol. 19 (2010), pp. 423-438.

SCHMEDDING, Detlef, Unrichtige Konzernrechnungslegung: zur Strafbarkeit unrichtiger oder verschleiernder Darstellungen im neuen Konzernbilanzrecht nach § 331 Nr. 2 $H G B$, Heidelberg: Müller, 1991.

SCHÜNEMANN, Bernd, "The Sarbanes-Oxley Act of 2002: A German Perspective", Buffalo Criminal Law Review, $\mathrm{N}^{\circ} 8$ (2004), pp. 35-50.

Unternehmenskriminalität und Strafrecht: eine Untersuchung der Verantwortlichkeit der Unternehmen und ihrer Führungskräfte nach geltendem und geplantem Straf- und Ordnungswidrigkeitenrecht, Köln: Heymann, 1979.

SCHÜPPEN, Matthias, Systematik und Auslegung des Bilanzstrafrechts, Köln: Schmidt, 1993.

SORGENFREI, Ulrich, "Bilanz-Strafrecht und IFRS", PiR, (2006), pp. 206-212.

"Zweifelsfragen zum „Bilanzeid" (§ 331 Nr. 3a HGB)", Wistra, (2008), pp. $329-336$. 
Polít. crim. Vol. 11, № 21 (Julio 2016), Art. 10, pp. 264-306.

[http://www.politicacriminal.cl/Vol_11/n_21/Vol11N21A10.pdf]

TIEDEMANN, Klaus, Tatbestandsfunktionen im Nebenstrafrecht : Untersuchungen zu einem rechtsstaatlichen Tatbestandsbegriff, entwickelt am Problem des Wirtschaftsstrafrechts, Tübingen: Mohr, 1969.

, Wirtschaftsstrafrecht: Besonderer Teil mit wichtigen Rechtstexten, 3. Aufl., München: Vahlen, 2011.

Wirtschaftsstrafrecht: Einführung und Allgemeiner Teil mit wichtigen Rechtstexten, 4. Aufl., München: Vahlen, 2014.

TORRES SALAZAR, Gabriel, Estados Financieros, 4a ed., Santiago: Editorial Juridica Conosur, 2001.

VARGAS, Tatiana, Falsificación de instrumento privado: un estudio práctico entre la falsificación y la estafa, Santiago: Legal Publishing, 2013.

WAßMER, Paul, "Vorbemerkungen zu $\S \S 331-335 b$ (HGB)", en: HENNRICHS, Joachim; KLEINDIEK, Detlef; WATRIN, Christoph (Eds.), Münchener Kommentar zum Bilanzrecht II $\S 238$ - 342 e HGB, München: Beck, 2013, pp. 1-65 n.m.

WEBER-GRELLET, Heinrich, Bilanzsteuerrecht, 13. Aufl., Münster: Alpmann Schmidt, 2015.

WILENMANN, Javier, "Sobre la estructura dogmática de los delitos de falsedad en el proceso", Ius et Praxis, № 2 (2014), pp. 71-108.

WILHELM, Jan, Kapitalgeselschaftsrecht, 3. Aufl., Berlin: De Gruyter Recht, 2008.

WINTER, Jaime, "Derecho penal e impunidad empresarial en Chile", Revista de estudios de la justicia, $\mathrm{N}^{\circ} 19$ (2012), pp. 91-195.

WITTIG, Petra, Wirtschaftsstrafrecht, 3. Aufl., München: Beck, 2014. 